\title{
The politics of Buddhist revival: U Dhammaloka as social movement organiser ${ }^{1}$
}

\author{
Laurence Cox, National University of Ireland Maynooth
}

\begin{abstract}
This article explores some important aspects of U Dhammaloka's Buddhism, drawing in particular on the work of his Rangoon-based Buddhist Tract Society between 1907 and 1910. It explores his work - in the Society and more generally - as in effect a social movement organiser within the Buddhist Revival, looking at his funders, publishers, printers, translators and distributors as well as those who wrote about him, laid down their hair for him to walk on, covered his train or boat fares, put up his friends in monasteries or let them cross borders, etc.

It also looks at what we know about his organisations and involvement in other people's organisations, asking who heintended to mobilise and who his audience was, how his use of confrontation and polemic fitted into this, and how successful he was. Following this, it goes on to discuss the intellectual sources of the free-thinking (atheist) positions espoused in the Society's publications, and asks more generally how his posture can be located in relation to the politics of plebeian free thought in Ireland, Britain, the US and Asia.

These questions arose out of an attempt to shed some light on the missing half-century before Dhammaloka became a public Buddhist figure; while the article can give no definite answers in terms of organising experience, intellectual inheritance or formative backgrounds, it suggests an alternative perspective which highlights a substantial, internationally-connected "Workers' University", grounded in the freethinking cultures of self-taught plebeian radicals, at the roots of western Buddhism.
\end{abstract}

\footnotetext{
${ }^{1}$ This paper is deeply indebted to the work of Alicia Turner and Brian Bocking on Dhammaloka, and is intended to complement their articles in this issue.
} 


\section{Introduction: the search for Dhammaloka}

\section{Who was Dhammaloka?}

U Dhammaloka, the Irish bhikkhu, was a complex and no doubt deliberately mysterious character. In the first decade of the twentieth century, he was vividly and publicly present - idolised by Burmese crowds, hobnobbing with Buddhists, theosophists and temperance advocates across Asia, denounced by missionaries, engaging in lively controversy in the newspapers, founding organisations, interviewed by journalists, tangling with the law, printing and distributing tracts, corresponding with western freethinkers, and even, perhaps, being mythologised in boys' adventure magazines.

Despite the methodological difficulties involved, researching Dhammaloka is highly enjoyable. Quick-witted, fiery-tempered, charming and sociable, his exploits as hobo turned monk, Irish Catholic turned scourge of missionaries, world-traveller and traveller between worlds make for fascinating reading - even if the truth is sometimes hard to establish. There is rarely a dull moment in what we know of his life - and enough unknowns to fit within the world of Arthur Conan Doyle, J ohn Buchan and Rudyard Kipling. At least from the point of view of the colonial whites of his day, he appeared with a bang out of total obscurity in 1900, and vanished equally mysteriously a decade later.

Dhammaloka's is also, as the Introduction has argued, a significant life, both in its own right and in the less well-documented lives it opens a window onto. Certainly Buddhist tradition has always seen beginnings as important; and Dhammaloka is almost certainly earlier than those usually recognised as the first European monks, as well as being the first known European to conduct a Buddhist ordination. He gives us a precious insight into the world of other "sailor-monks" and plebeian western Buddhists in turn-of-the-century Asia; if late twentieth-century Buddhist Studies was keen to emphasise the "gentleman scholar" aspect of early western Buddhism against the "Beat Buddhist" and "hippy trail" tendencies of its students, Dhammaloka shows us that Beat Buddhism may not have been such a historical aberration after all.

Along with class, Dhammaloka gives us an important insight into the anti-colonial politics of early Buddhism. Contradicting the assumption that early western Buddhists were necessarily pro-imperial Orientalists, it turns out that it was not just Asian Buddhists who mobilised against colonists and missionaries in this period. The long-term linkages between Indian and Irish nationalists seeking to weaken or overthrow imperial power have long been known. Recent research has highlighted connections between cultural nationalists in both countries and relationships around religion, particularly via the Theosophical - Hindu link².

The extent to which Buddhism facilitated such anti-colonial networking - in this case between Ireland and Burma, then part of India - has not hitherto been studied. Elsewhere,

\footnotetext{
2 Tadhg Foley and Maureen O'Connor (eds.), Ireland and India: Colonies, Culture and Empire (Dublin / Portland: Irish Academic Press, 2006).
} 
I have discussed Dhammaloka as a key example of a series of known early Irish Buddhists and Buddhist sympathisers in Asia (Lafcadio Hearn, J ohn Bowles Daly, Maurice Collis, Patrick Breslin) whose organisational loyalties were to Asian organisations and for whom opposition to missionaries was part and parcel of their Buddhist sympathies 3 . He represents an Irish "rabble-rouser" drawing on the long-standing repertoire of Catholic nationalism in Ireland - building anti-colonial identity through religious self-assertion to contribute to the formation of Burmese Buddhist identity while directly attacking the Christian missionary effort to the point of being condemned for sedition.

Dhammaloka's opponents (and no doubt his supporters) were in no doubt as to the political implications of his defence of Buddhism and attacks on missionaries: behind the critique of Christianity lay a critique of colonialism, and his work fits into those aspects of the Buddhist Revival which can usefully be characterised as cultural nationalism, the formation of ethnic and anti-colonial identities around a religious assertion which was hard for colonial powers to attack directly. Here Dhammaloka's Irishness becomes particularly important, and we can consider his activities (between Ireland and Asia, but also between different Buddhist countries in Asia) as part of the transmission of a transnational "repertoire of contention"4.

The notion of a repertoire of contention, however, raises interesting possibilities for researching the "missing half-century" of Dhammaloka's biography. Elements such as organising style, intellectual heritage and formative milieux often make it possible to trace back how someone has learned their activist trade, who their maîtres à penser were, and where they first became publicly active. Usually, of course, this is not done as a detective exercise but with the benefit of hindsight and at least the basic biographical facts to hand. Or, we might say, it is rare for someone to become an effective movement organiser in their fifties from scratch.

This article uses this perspective to explore Dhammaloka's (known) life and career, in three dimensions. Firstly, it is clear that his activities - notably the Buddhist Tract Society (BTS) in Rangoon, his preaching tours and "media work", various Young Men's Buddhist Associations (YMBAs), and his mission and school in Singapore, but also other involvements such as temperance lodges and (perhaps) freethought associations - were quintessentially organising activities, geared to raising awareness, mobilising supporters and creating organisations. Like other figures of Buddhist Modernism, Dhammaloka's Buddhism was not a solitary retreat from the world but a head-on engagement with it ${ }^{5}$. The first section of this article explores Dhammaloka from this point of view, as social movement organiser6.

\footnotetext{
${ }^{3}$ Laurence Cox, "Plebeian freethought and the politics of anti-colonial solidarity: Irish Buddhists in imperial Asia". Paper to Alternative Futures and Popular Protest conference, Manchester (2010).

4 Sidney Tarrow, Power in Movement: Social Movements and Contentious Politics ( $2^{\text {nd }}$ edition, Cambridge: Cambridge University Press, 1998).

${ }^{5}$ David McMahan, The Making of Buddhist Modernism (Oxford: Oxford University Press, 2008).

${ }^{6}$ In section I in particular I draw on social movement studies as well as my own experience as activist, editor of non-profit periodicals and Buddhist organiser to evaluate Dhammaloka's achievements in these areas.
} 
Secondly, one distinctive feature of Dhammaloka's Buddhism is its aggressive use of freethinking (atheist) arguments derived from American and British freethought, represented particularly in his correspondence with western freethinkers, his translations and reprintings of free thought texts, and part II of this article explores this intellectual inheritance. Thirdly, a consideration of what is known about the milieux of working-class free thought and their relationships with political critique and spiritualism might be expected to yield results; and part III explores this avenue.

\section{Scholarly questions and hobo answers}

As will be seen, these questions do not, alas, enable us to pinpoint the prior identity (and no doubt fascinating biography) of the man who was to become U Dhammaloka. The ways in which these are the wrong questions, however, point towards centrally important facts about the nature of his world and activities. In a nutshell, they are questions easily asked of those with formal educational training, with continuous public histories, who founded organisations that survived and worked through the official institutions of the day. They are not quite the right questions to ask of those whose education was largely self-made, who took pains not to have their identities too well-defined, whose organising activity did not outlast them and who were far from socially respectable. In the terms of our Introduction, they are "gentleman scholar" questions asked of hobos.

We have seen that if Dhammaloka vanished from English-language accounts of early Buddhism, this was not the case for all of his contemporaries. Later writers were concerned to record facts and construct organisational genealogies (or founders' hagiographies) for traditions which survived. Thus Ananda Metteyya's (retrospective) position as one of the founders of western Buddhism has ensured the survival of a host of information about his life and activities which no successors recorded for Dhammaloka7.

This is primarily an accident of history; if figures like Dhammaloka gave less attention to organisational sustainability and more to agitation, this does not mean that they were less active or effective; at the time and on the ground, the reverse may often have been the case.

It is, however, a problem for researchers. We may yet hope to find Asian-language records which give a clearer sense of the man as seen by his allies and supporters, and thus better understand the particular "Buddhist politics" he espoused; but as matters stand most of what we know of his views derives from his republishing of other authors' work, and much of what we know of his activities comes from his opponents - who were in most cases not only hostile, but lacked access (for class, ethnic and linguistic reasons) to the Asian contexts in which most of his work was done.

Matters are worse still when we try - as Brian Bocking, Alicia Turner and myself have done - to trace his life back to what by his own account was a life as migrant worker in the States, or to identify one of the various names he claimed - O'Rourke, Carroll, Colvin -

\footnotetext{
7 On Metteyya see Elizabeth Harris, Ananda Metteyya: The First British Emissary of Buddhism, Wheel Publication No. 420/422 (Kandy: Buddhist Publication Society, 1998) and J ohn Crow, "The White Knight in the Yellow Robe: Allan Bennett's Search for Truth" (Master's thesis, University of Amsterdam, 2009).
} 
with Irish records. The effectiveness and determination of his agitation for freethinking Buddhism across Asia between 1900 and 1911 implies a background where he learnt these skills; but unless we can identify him in one of the various worlds of working-class activity of the period - union organising, socialism, anarchism, atheism, spiritualism, Irish nationalism - we have no records of the man before 1900.

Nevertheless, as I hope to show, while it is not possible with any confidence to assign Dhammaloka's thought to a particular national context, he fits well enough into a substantially shared world of working-class hostility to established Christianity that stretched from Dublin to London to Chicago to Rangoon. Plebeian free-thinker, selfeducated agitator, migrant worker gone native - Dhammaloka's Buddhism comes to us out of worlds whose voices and names are easily lost.

Thus while this article is in a sense a work of intellectual history, it is a work whose primary figure speaks far less in his own voice than is usual for such work. For this reason, this chapter includes extensive excerpts from some key "Dhammaloka texts" in which he gave extended statements of his own position ${ }^{8}$.

\section{I) Dhammaloka as social movement organiser}

Dhammaloka was in many ways a classic social movement organiser. He founded Buddhist, freethought and (perhaps) temperance organisations in Burma, Siam and Singapore; was networked with Buddhists in India, Nepal, Ceylon, J apan and China; and held extensive speaking tours polemicising against Christian missionaries throughout Burma. An energetic writer and self-publicist, his organisations published and distributed very large numbers of pamphlets, while he engaged in extensive newspaper controversy and in correspondence with the US, Canada and Britain; he was not afraid of strategic confrontations with authority and on at least two occasions wound up in court. Reviled by missionaries and much of the colonial press, he was very popular among ordinary Asians in several countries (this is attested for India, Burma and Singapore), and made a significant contribution to cultural nationalist opposition to an empire which was increasingly legitimated at home through missionary religion.

This section uses what is known about the character of his organising work, or (as we might now say) the nature of his practice as "engaged Buddhist", as one possible indication of where he might have learned the organising trade. I start with his publishing career, which is (perhaps inevitably) the best-recorded aspect and provides an insight into his general organising capacity - funding, translation, publishing and distribution. Following this, I give a more general overview of what is known about his other organising activities, and discuss aspects such as funders, supporters and audiences, controversy and organisational sustainability by way of giving an overall sense of his "organising style".

\footnotetext{
${ }^{8}$ His sermons probably represented a similar kind of length and approach, and presumably overlap with texts such as these to some extent. See e.g. the report in "Bassein", Times of Burma, February 16, 1901, 5-6.
} 


\section{Dhammaloka as publisher: the Buddhist Tract Society and before ${ }^{9}$}

The Buddhist Tract Society represented a substantial piece of organising in its own right, as well as being apparently the culmination of a long period of work in this direction. Initially, Dhammaloka seems to have relied on newspapers to spread his message ${ }^{10}$. Along with letters to the papers and "correspondents' reports" in press release style, written by Dhammaloka or an assistant, there is a series of tracts and open letters, such as the one which marks his first effective public appearance, entitled "A warning to Buddhists".

This piece had a remarkable reception history, perhaps because of the radical and innovative nature of his position at the time. Described by the Times of Burma as "The most remarkable circular [which] has begun to appear in Akyab", it was carried in the leading article of the Arakan Times and picked up by the Times of Burma before travelling around the world, both to the freethinking press - Das freie Wort in Frankfurt and Rufus Noyes in Boston - and Christian periodicals - "a Chicago denominational journal" which was then in turn cited by the Salt Lake City Deseret Evening News"11. The text is worth citing in full to give a sense of Dhammaloka's perspective and style ${ }^{12}$ :

\section{Warning to Buddhists}

Buddhists of Burma! Be warned in good time! Do your duty! The Christian belief is slowly making way. It has, in Europe, a strong and powerful organisation. It is backed up by gigantic hoards of money. It works secretly and stealthily. It appeals forcibly to the self interest and cupidity of men. One Missionary Society in South India has spent during the last year on an average 10,000 rupees for a single convert! No wonder that it has been able to make 1,000 converts. Buddhists laugh and sneer when they are told that Christianity is progressing. If, when Christian missionaries are prepared to spend annually at the rate of 10,000 rupees for a single convert, they can only make 1,000 converts how, they ask, can

\footnotetext{
${ }^{9}$ The content of these tracts is discussed in part II of this paper.

${ }^{10}$ His use of the colonial English-language press is discussed in the articles by Brian Bocking and Alicia Turner; work is now starting on the Asian-language press to see whether and how he is represented there

11 The Times of Burma, January 9, 1901; Arakan Times, December 29, 1900; Das Freie Wort 1, no. 1 (1901), 191 - 2, Rufus Noyes, Views of Religion (Boston: LK Washburn, 1906, 48); Deseret Evening News, August 24,1901 . Noyes was a medical doctor and founder of the "materialist movement", who authored texts entitled The self-curability of diseases; a History of medicine for the last four thousand years and The science and art of ignorance; or, The conspiracy of Christian ministers, press and theologians against humanity. He seems to have been an early associate of Mary Baker Eddy, founder of Christian Science, and attended her husband on his deathbed, but apparently publicly criticised her claims about the miraculous nature of that death (J ames Snowden, The Truth about Christian Science: The Founder and the Faith, Philadelphia: Westminster Press, 1920,48 - 9).
}

${ }^{12}$ Here I use the Freie Wort's German translation to fill out the Times of Burma's English version, which lacks the opening. 
there be any danger, near or remote, to our religion and society? But this is to under-rate the pecuniary strength of our adversary. Christian Missionary Societies are so enormously rich that they can afford to spend a good deal more. Therein lies our danger. Christianity, as a system of religion, is sorry stuff. Unbelief is steadily gaining ground in Europe. Look at the lawlessness in the Church of England at the present time. No wonder! The other day three Christian Bishops came together at Manchester and openly confessed how the advance of science was making it impossible to continue to believe in many of the fundamental doctrines of Christianity. As science advances, belief in Christianity is fading in Europe. Christianity spreads in this country, not because it has any intrinsic worth - for science has shown it has none - but because its Missionaries are backed up by the powers of the purse. Of our own great religion, a European scientist has said: - "Buddhism is perfectly compatible with science: Christianity is diametrically opposed to it. Scientific thought has made its way in spite of Christianity; and it is by means of scientific thought that Christianity is ultimately destined to perish." It is perishing in Europe, but money makes it thrive here, while our own scientific Gospel - Buddhism - is daily being robbed of its votaries. Buddhists of Burma! Reflect well on our dangers. Can you bear to see sacrilegious hands deface or destroy our holy inheritance? The star-like Buddhas are calling upon you to proclaim from house-top and hill-side, from meadow and valley, the sacred gospel which they have entrusted to you. Will you showyourselves worthy of the trust? We have slept long enough, shall we not at least, with a great and grave danger looming before us in all its huge and hideous proportions, shake off our lethargy? Buddhists of Burma! Rise then and gird up your loins for the coming struggle. May the Blessed Lord Buddha guide your efforts, prosper them and crown them with reward!

This circular launched Dhammaloka on a ten-year publishing career, in the course of which he became widely known in both Asia and America as correspondent, author and publisher. We do not have anything like a complete publication history for his work, and many of the texts mentioned in this article are known to us by name only. This is the case, for example, for two 1901 tracts," Unity is strength" 13 and "Revival of Buddhism", a piece by a Scottish Maha Bodhi representative which Dhammaloka published through the Chinese Cycling Society (!) ${ }^{14}$, a 1904 Declaration in the Singapore Straits Times and an open letter to Christian missionaries, "What is the use of prayer?", mentioned in the

\footnotetext{
13 The title was perhaps borrowed from the trade union slogan: Cotes ("Ordination of Asoka", 758) quotes him as preaching "They say union is stren'th".

${ }^{14}$ The Times of Burma (April 17 1901) has the following notice: "Revival of Buddhism by Major General Dawsonne Strong, C.B. representative in Scotland of the Maha-Bodhi Society, 8, Drummond Place, Edinburgh. Published for free distribution by the Chinese Cycling Society through Revd. U. Dhammaloka, (the Irish Phongyee). Copies free on application."

Later on Dhammaloka was to produce an epitome of the writings of Robert Blatchford, "Nunquam" of the Clarion - a British socialist and freethinking journal best known for being distributed by the Clarion Cycling Club (still in existence: Dennis Pye, Fellowship is Life: the National Clarion Cycling Club, 1895 - 1995, Bolton: Clarion, 1995). Whether there is any link between the plebeian radicalism of the Clarion club and the Chinese Cycling Society's publication of Revival of Buddhism is unknown, but it would provide an explanation for this connection.
} 
Straits Times in 190515. An anti-missionary article (perhaps another open letter), entitled "United Burma" appeared in J une 190716. Our research has thrown up a constant stream of such references and texts, and we can expect to find more as we explore new sources.

Along with such relatively substantial, pieces, Dhammaloka was active as a newspaper correspondent, contributing short reports (following the practice of the day, these are usually unsigned and in some cases pseudonymous) as well as letters (signed and pseudonymous) to newspapers in Burma, Siam and Singapore, as well as short reports and news items for American periodicals ${ }^{17}$. This prolific, but relatively small-scale activity, was typically an adjunct to his preaching and lecturing work.

\section{Foundation of the BTS}

Two significant, and perhaps related, changes seem to have come about around 1906 - 7. One was in terms of format: with the exception of the Chinese Cycling Society tract, Dhammaloka seems to have relied up to 1907 almost entirely on newspaper pieces as printed amplifications of the positions he was expounding in preaching tours, whereas after this point his focus seems to have shifted to publishing tracts. In both periods, however, he was happy to use the press as a site for publicity through (usually unsigned) articles describing his activities and projects, and to defend himself in the letters pages against various criticisms.

The other change was in terms of authorship: he seems to have scaled down his writing of longer self-penned pieces in favour of a greater reliance on republishing or translating the works of others, particularly western freethinkers - with interpolations of his own as well as a miscellany of shorter pieces of his own composition, letters and advertisements at the back. This entailed a slight shift of emphasis, with more focus on the positives of Buddhism in the earlier period and - inevitably given the use of western freethinkers as source material - a greater focus on criticising Christianity in the later, but there is sufficient of both types in both periods to make it clear that this was an effect of reprinting rather than a conscious choice.

In any case, this change marks a qualitative leap in organisational terms, implying steady funders, advertisers, at least one translator, a long-term relationship with a publisher and good distribution networks. It may be that the shift from self-published works to what was in effect working as an editor made sense in terms of what was in any case a fairly substantial organisational workload by this point.

\footnotetext{
${ }^{15}$ Straits Times March 9, 1904, 5 and J anuary 19, 1905. The latter, discussed in Brian Bocking's article, may have remained unpublished.

16 WCB Purser, Christian Missions in Burma (London: SPCK, 1911: 217).

${ }^{17}$ Alongside his correspondence with freethinking periodicals, and the reports they carried on his activities, no doubt based on information he provided, Dhammaloka's presence in the mainstream American press was commented on by various writers, including hostile (Christian) sources. As yet, however, we have been unable to locate these pieces, in part no doubt because the periodicals he is likely to have used have not been as extensively digitised as daily newspapers.
} 
We can possibly see him casting around to find a workable model in the run-up to the BTS' foundation: perhaps around 1906, he was quoted as saying

I have asked a bookseller to order twenty copies of Remsburg's [freethinking] work ${ }^{18}$.

In 1907 he published the 64-page tract Buddhism or Christianity, which? in Colombo ${ }^{19}$ (Peebles 1907), suggesting that he may have been actively seeking a stable publishing source and settled on Rangoon as a base after trying Colombo (where other forms of Buddhist revival were considerably better-established). By the end of the year, however, the Buddhist Tract Society was in operation and based in Godwin Road in Rangoon, where it was to continue issuing tracts until at least 1910; a society of the same name was in existence in Mandalay between at least 1917 and 1921, and may have been a continuation after Dhammaloka's death or emigration ${ }^{20}$.

As a series, the BTS tracts bring to mind the Rationalist Press Association's Thinker's Library - largely reprints of rationalist texts (albeit by more polemical and less respectable authors), in a cheap and accessible format, aimed at mass distribution. Part II discusses the content of the series; for now we can note that they appeared in a standard $(16 \mathrm{~cm})$ format, very like that used by the Society for Promoting Buddhism in Mandalay with which he was associated, but with the BTS logo (Alicia Turner pers. comm.) The recorded lengths include 31, 48 and 63 pages. His earlier texts may have been shorter, perhaps transcripts of sermons or texts like his "Warning to Buddhists", which would fit comfortably on one page), which might account for their failure to survive (or our failure to locate them).

The BTS used the Burma Echo as printer and co-publisher, which perhaps explains the particular attention the Echo gave to its doings, in articles probably contributed by Dhammaloka himself. This gives us a good insight into the workings of the BTS, at least as its chief organiser wished it to be seen. Thus in 1907 the Echo reported:

Buddhist Tract Society-- At a meeting of this society held at its headquarters in the Godwin Road on Sunday last [1907], it was resolved to publish and distribute broadcast throughout Burma one hundred tracts (ten thousand copies of each) to be sent out free by the end of the year ${ }^{21}$.

In the same year, an unsigned piece in the Echo (which may have been written by Dhammaloka), noted

\footnotetext{
18 Sheffield Ingalls, History of Atchison County, Kansas (Tucson: Americana, 1974, 506).

${ }^{19}$ Advertisement in J ames Peebles, What is Buddhism? (Colombo: Sri-Dharma-Sri publishers, 1907 - 8, 32). This text is puzzling because one of an identical name and length was apparently published by C. W. G. Withee in 1910. Around this period Dhammaloka was writing to the Humanitarian Review to order copies of other tracts by Withee. It is possible that one or other was plagiarising, or that someone mistook publisher for author in Ceylon or America - or indeed that a title like this was sufficiently common to be widely used. Certainly freethinkers of the period, like their journalist contemporaries, had a "cut-and-paste" approach to their work which would cause severe problems today.

${ }^{20} \mathrm{U}$ Kyaw Hla of the Buddhist Tract Society in Mandalay is mentioned in the Buddhist Society of Great Britain and Ireland's Buddhist Review (vols. 9 - 11, 1917, 194), as well as in the Eastern Buddhist (vol. 1, 1921, 392) and the Maha-bodhi (vols. 29 - 30, 1921, 120, 200, 345).

21 "Buddhist Tract Society," Burma Echo, September 14, 1907. 
The Buddhist Lent began on the $24^{\text {th }} \mathrm{J}$ uly last, and will end on the $23^{\text {rd }}$ inst. The $21^{\text {st }}, 22^{\text {nd }}$ and $23^{\text {rd }}$ will be great festival days at the Shwe Dagon Pagoda temple, and the Buddhist Tract Society intend distributing on each of these three days, 25,000 copies of their tracts, or 75,000 copies in all ${ }^{22}$.

Eventually we have this:

B.T.S.-A special meeting of the Buddhist Tract Society, Executive Committee will be held tomorrow morning at 10am to consider how to meet the present demand for tracts and other literature ${ }^{23}$.

\section{In 1908 the Echo noted}

The American Baptists were holding the yearly gathering of their Upper Burma flock at Mandalay, the other day [1908] when U Dhammaloka (the Irish hpoongyi) representative of the Buddhist Tract Society accompanied by two stalwart Punjabees proceeded to the place of the meeting; and there distributed some thousands of pamphlets among the American Baptist Mission's flock of both sexes.

These pamphlets are being distributed von the main roads and on the platform of pagodas in Mandalay causing some stir in religious circles24.

\section{In Henzada}

The Buddhist Tract Society has flooded the town with their anti-Christian tracts ${ }^{25}$.

\section{Similarly, in Myingyan}

The Buddhist Tract Society has been very active; and their tracts have been widely circulated amongst all classes of the community which tracts are very anti-Christian and are deliberate attacks on the Christian faith ${ }^{26}$.

No doubt the printing contract was a lucrative one; and if the Echo had every reason to highlight the significance of the BTS tracts, this was presumably due to the scale of its operations, which are confirmed from other sources, including hostile ones. The BTS was expanding in this period; the Myingyan branch opened in February 1908, joining the existing Rangoon and Mandalay branches (the date of the Henzada one is not known) 27.

In 1909 correspondence with the Kentucky Blue-grass blade (discussed below) Dhammaloka claimed to have sold over 10,000 copies of Tom Paine's Age of Reason in 1908 along with some copies of the Rights of Man; presumably these were BTS editions. Certainly the projected translation into Burmese of Age of Reason which he mentioned at this point was ${ }^{28}$.

By 1910, the missionary Francis Clark noted that

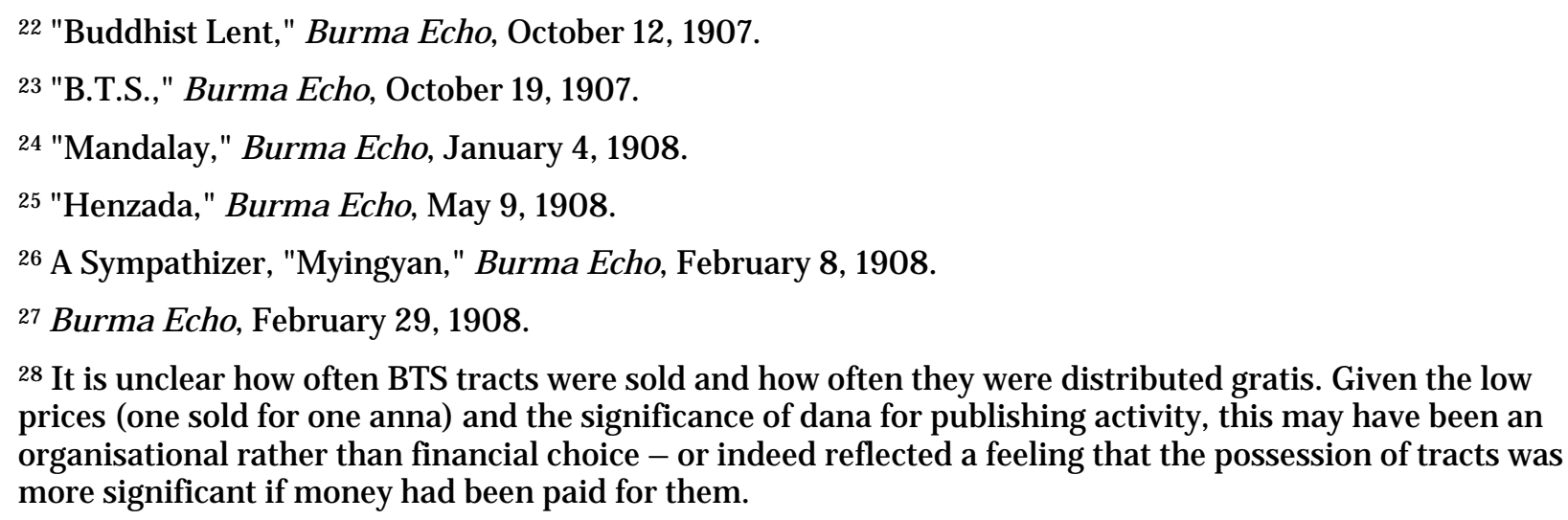
prices (one sold for one anna) and the significance of dana for publishing activity, this may have been an organisational rather than financial choice - or indeed reflected a feeling that the possession of tracts was more significant if money had been paid for them. 
A 'Buddist [sic] Tract Society' is sending out its books and leaflets by the million.

Describing the Shwedagon pagoda, he commented

This busy combination of mart and temple the Buddhist Tract Society has chosen as a rare strategic spot from which to disseminate its doctrines, and here is a stall filled with its literature. (1910: 248)

Later, in his autobiography he recalled

The colporteurs of the "Buddhist Tract Society" distributed literature in English to us, deriding

Christianity and praising Buddhism ${ }^{29}$.

The Society, then, was an active reality on the Burmese scene in the years around 1910. I shall return to the question of scale shortly, but want here to ask about its international sister organisations.

\section{BTS International? Excursus}

As with other such titles (Young Men's Buddhist Associations, Society for Promoting Buddhism, Societies for Buddhist Endeavour, etc.), a title like "Buddhist Tract Society" is clearly calqued on a Christian original. Such calque-organisations were a widespread feature of the Buddhist revival, so that the existence of societies with a similar name outside Burma does not necessarily imply any organisational relationship.

The parallels, however, are useful in terms of shedding light on the practical side of things. In China a BTS already existed in the 1880s:

There came one day to a chapel in a country town a middle-aged man named Tong. He was giving away tracts published by a Buddhist Tract Society. The particular kind that he had in his hand at the moment was a yellow leaflet with fourteen sentences, encouraging men to righteousness of life.

Another missionary noted

We were surprised to find a Buddhist Tract Society shop in the city [Hangchow]; we bought several books, and among them a guide to the Buddhist Temples. It gave the numbers of the monks, which ran into the hundreds at some of the temples.

This Chinese society seems perhaps more stably distributed than its Burmese counterpart. The Ceylon Society seems to have been of a similar vintage to the Chinese:

Prints, both in Sinhalese and English, are freely distributed by a Buddhist Tract Society. These things come to the hands of schoolboys, and error is sown...

From the Theosophical side, Lucifer notes

there is in that island a positive "revival" of Buddhism, stimulated in part by the Theosophists. The priests copy the plans of the missionaries, and strive to counteract them by education and by the use of the press. They have been trying to wile away children from mission schools. The latest movement among them is a proposed Hindu-Buddhist college, to counteract missionary colleges. They circulate the publications of the Buddhist Tract Society, the Buddhist Aid Association, and the Buddhist Theosophical Society...

\footnotetext{
${ }^{29}$ Francis Clark, "Buddhism on the warpath", The Independent: A Weekly J ournal of Free Opinion, Devoted to the Consideration of Politics, Social and Economic Tendencies, History, Literature and the Arts, February 3, 1910, 246 - 9; Memories of Many Men in Many Lands (Boston and Chicago: United Society of Christian Endeavour, $2^{\text {nd }}$ edition 1922, 387).
} 
One missionary's biographer gives a sense of the scale of this activity:

A Buddhist Tract Society is as active in Ceylon as the Hindu Tract Society is in Madras. Replies, in editions of 8000 copies, have been printed in Sinhalese...

Young and Somaratna also note the figure of several thousand copies each of BTS volumes ${ }^{30}$. Dhammaloka may have taken the idea from Ceylon, where he had just published a text prior to establishing the Burmese BTS. In any case, it seems that the basic scale and mechanisms of such societies were fairly straightforward, and we need not posit too much quantitative exaggeration in the Burmese case.

\section{Organisational implications of Dhammaloka's publishing}

Both hostile as well as potentially interested sources concur that the scale of BTS publication (and hence funding) was substantial. It is of course possible that the larger figures mentioned are exaggerations; it should, however, be borne in mind that for an orthodox Burmese Buddhist sponsoring the printing of religious tracts would be a highly meritorious act.

In any case we are talking about considerable print runs and multiple titles (anywhere between the 8 titles known to us so far and the 100 mentioned in 1907), with enough supporters to organise what seems to have been a fairly extensive distribution process. Even if all experience of small political printing suggests that it is easier to print than to distribute, we know that bookstalls were manned and tracts handed out in Rangoon, Mandalay, Henzada and Myingyan at least. No doubt the tracts were also sent to associated organisations and distributed during preaching tours, and in at least some cases sold which requires further organisation.

The BTS also raises linguistic issues. Dhammaloka must have had at least one translator available for the Society, which published at least two works in Burmese ${ }^{31}$. According to Donogh, the sedition for which Dhammaloka was charged (part of a preaching tour in Moulmein) took place through interpreters ${ }^{32}$. While he claimed to Franck to speak 8 languages, and demonstrated at least some of this, this may well have been a rough-and-

30 Edwin Dukes, Everyday Life in China: or, Scenes along River and Road in Fuh-kien (London: Religious Tract Society, 1885: 214); Timothy Richard, Forty-five Years in China: Reminiscences (London: Fisher Unwin, 1916, 272); Wesleyan-Methodist magazine 1889, 209; Lucifer / Theosophical Review (1890, vol. 6, 349); Henry Morris, Life of J ohn Murdoch LLD: the literary evangelist of India. London: Christian Literature Society for India, 1906, 136); Richard Young and GPB Somaratna, Vain Debates: the BuddhistChristian Controversies of Nineteenth-Century Ceylon (Vienna: de Nobili Library, 1996, 210).

${ }^{31}$ It should be understood that most Burmese Buddhists of the period would have felt it meritorious to have Buddhist books in the house, quite separately from any intention to read them (or indeed literacy in Burmese, let alone Pali or English). The language of publication is thus only loosely connected to any sense of audience, and all the evidence suggests that the BTS tracts were intended for a mass public.

32 Bizarrely, in Bassein in 1901 his speeches were said to be "interpreted to the Burmese audience by a Chinese gentleman". "Bassein", Times of Burma, February 16, 1901, 6. 
ready vernacular; he could not read either Pali or Burmese ${ }^{33}$. Until recently monks had preached either in Pali or a Burmese Pali hybrid that was far from everyday speech; the use of interpreters suggests, however, a concern to be understood and to make a formal impression ${ }^{34}$.

Finally, we can note Dhammaloka's access to the printing and publicity possibilities of the Burma Echo and his ability to publicise his work prior to that even through hostile media.

Thus, if at one level Dhammaloka often appears as a one-man band, his publishing activities make it clear that we have to understand him as surrounded by a (perhaps shifting) number of supporters or allies - the "stalwart Punjabees" who helped him leaflet and perhaps also manned the bookstalls, his interpreter(s), the translator(s) at the Society, a printer (who was also a sympathetic newspaper editor), various sponsors, a treasurer, and so on. Keeping this machine running - however it was done in the course of a life spent travelling, preaching and founding organisations - implies a continuing organisational effort; and the BTS was not his only organisation.

\section{Building the Buddhist revival}

Dhammaloka was both a "joiner" and an inveterate founder of organisations; in the nature of things, it is not always clear in specific cases what his relationship was. What follows is an (incomplete) list of his organisational activities; the articles by Alicia Turner and Brian Bocking discuss various aspects of these in greater depth.

In Burma, Dhammaloka was involved in the organisation of multiple Buddhist bodies. He preached for and was sponsored by the Mandalay-based Society for Promoting Buddhism as well as claiming (in the Bangkok and Singapore press at least) to be its president. Cotes records him describing the Society's object as being to "spread Buddhyism in all people whatsoever color they are" 35 . The Society's corresponding secretary Maung Maung seems to have been one of his closest associates for some years. He also founded "Buddhist Endeavour Societies" 36 and at least floated the foundation of a school:

Under the lead of the Irish Pongyi, or priest, the Buddhist Society have voted to start a "King Edward Memorial Buddhist Boy's School" in Pyinmana, Burma ${ }^{37}$.

\footnotetext{
33 Walter Donogh, The History and Law of Sedition and Cognate Offences in British India...(Calcutta: Walter Spink, $2^{\text {nd }}$ edition 1914, 216); Harry Franck, A Vagabond J ourney around the World: a Narrative of Personal Experience (New York: Century, 1910); Mrs. Everard Cotes, "The ordination of Asoka". (Harper's Monthly Magazine, J une - November 1902, 753 - 760).

34 The Straits Times editor, incidentally, claims that Dhammaloka used an amanuensis (J anuary 19 1905, 4). In his article, Brian Bocking suggests that he may have been able to read but not write, in which case we need to add another assistant for his writing and editing work. It is also possible that the articles which we are ascribing to Dhammaloka should in fact be ascribed to an associate.
}

35 Straits Times, August 6 1903, 6; Cotes, "Ordination of Asoka", 758.

36 Bible Study Union Lessons 1910: 168; Clark, Memories of Many Men, 387.

37 Missions: an International Baptist Magazine, 1911, vol. 2, 133. 
Dhammaloka was also responsible for a Burma Freethought Association ${ }^{38}$, and was active in various temperance lodges, such as the "Pride of Rangoon", of which he was at one point president. To all of this we have to add his publishing and journalistic activities and the preaching tours discussed in Alicia Turner's paper.

In Singapore, Dhammaloka founded a Buddhist Mission which was at least moderately successful: it organised New Year celebrations in April 1904 in the course of which food was given to 3,000 poor people, and in October saw a novice ordained in the presence of Buddhists from various traditions. According to the Straits Times in the same year, it had sent a European and a Eurasian candidate to Rangoon for ordination; later it reported that new branches were due to open in Penang, Kuala Lumpur and Thursday Island in North Australia ${ }^{39}$.

Other projects, including a free English-language school, followed from this, as did "a Buddhist magazine" of which we have as yet no other record. The school, according to the Maha Bodhi (cited in the Straits Times), was a boy's school in "one of the poorest localities of Singapore, where the children of the factories around the locality can get a free English education as well as a religious education in the doctrines of our holy religion". A "Straits Young Men's Buddhist Association" is also mentioned as associated with his work ${ }^{40}$. As in Burma, he was also involved in the politics of Singapore temperance lodges.

In Siam, Dhammaloka founded a school in a populous working-class district with donations from Burmese merchants in Bangkok and Bombay, under the nominal auspices of the Society for Promoting Buddhism. This was free, secular, multi-ethnic (Siamese, Chinese, Malay and Indian) and operated through English, with 50 - 60 pupils (Bangkok Times and Weekly Mail May 2 and J une 5 1903). The Straits Times (August 6 1903: 6) records him as also responsible for the creation of "a Buddhist magazine, one or two other institutions in Bangkok". This was something of an understatement, at least on paper: he was associated with a Young Men's Buddhist Society and a Siam Buddhist Society (his last supposedly a joint venture of the Mandalay SPB, the J apan-based IYMBA and the Mahabodhi Society ${ }^{41}$ ), and proposed to build a Wat for visiting foreign Buddhists beside the existing Wat Dawn "as headquarters of the International Buddhist Association in Siam", as well as broaching a plan for an international Buddhist congress in Bangkok in 1904; neither this nor the new Wat came to fruition ${ }^{42}$. According to a Times of Burma report, Dhammaloka also co-founded a temperance club in Bangkok during this period. Finally, he may have "retired" from Burma to become president of a Buddhist Freethought Association in Siam ${ }^{43}$; organisationally at least, this would be completely in character.

38 George Macdonald, Fifty Years of Freethought: being the Story of the Truth Seeker, with the Natural History of its Third Editor (New York: Truth Seeker, 1931, 373); Purser, Modern Buddhism in Burma.

39 Straits Times April 28, 1904; October 1, 1904, 5.

40 Straits Times August 6 1903, 6; J anuary 2o 1904, 3, October 1 1904, 5.

${ }^{41}$ Bangkok Times and Weekly Mail, March 7 1903; J une 6 1903. The SBS may be the same as a Siam National Buddhist Association mentioned in the BTWM on J uly 24.

42 Bangkok Times and Weekly Mail, J une 10 1903; J une 231903.

43 Purser, Modern Buddhism in Burma.

14 
In J apan, he was present at the founding of an International Young Men's Buddhist Association, discussed in detail in Brian Bocking's article. This is presumably identical with the International Society for the Promotion of Buddhism with which he was associated in a newspaper article ${ }^{44}$ and the International Buddhist Association mentioned earlier.

While it is important to note that many of these organisations did not survive, or may only have been "letterhead organisations", this does not necessarily distinguish them from other Buddhist organisations of the period (as Brian Bocking's article notes). It was presumably always easier to find sponsors for new foundations than supporters for existing ones. Certainly the Burmese BTS and SPB, the Singaporean Mission and School, and the temperance lodges had some degree of longevity as well as real-world existence.

\section{Organisational strengths and weaknesses}

Beyond the points already mentioned, Dhammaloka's organisational strengths seem to be fairly clear. Lively and charismatic, he found it easy to secure funders or patrons as well as to recruit supporters and to gain popular support. He also had a gift for effective confrontation. Conversely, he was not good at what we might call organisational sustainability, or at encouraging his supporters to take on more active roles. I will consider these in turn.

\section{Funders}

Dhammaloka was perhaps more of a movement entrepreneur than a movement organiser: his funding strategies seem mostly to have revolved around the support of wealthy patrons, rather than developing any kind of membership- or mobilisation-based financial structure. In this, of course, he followed Asian Buddhist practice, where public donations for the good of Buddhism were understood to be meritorious acts in themselves, and in any case a normal part of the behaviour of those with enough wealth to make substantial contributions over and beyond those attendant on life-cycle rituals or local alms rounds.

Some of these funders were merchants: for example, Maung Maung was a Burmese gem merchant living in Bangkok who sponsored Wat Dawn school in Bangkok along with Maung Shwe Choung and Moung Bah Yit of Bombay. He was also correspondence secretary of the Society for Promoting Buddhism, accompanied Dhammaloka to J apan and subsequently to Bangkok. In Singapore, the Sinhala jeweller BP da or D'Silva sponsored the distribution of food to 3,000 poor people and a scholarship to Dhammaloka's school, as well as sponsoring other Buddhist projects 45 .

Gem merchants of course were often mobile and depended on strong international connections, as well as a good public reputation. In Burma at least, Dhammaloka's internal

\footnotetext{
44 Straits Times August 261903.

45 Straits Times J anuary 20 1904, 3.

15
} 
tours would have involved many donations of mobile wealth in the form of jewellery ${ }^{46}$, and as a monk he could not have handled such transactions in person.

Other benefactors in Singapore were Chinese businessmen: Cheung J im Chuan, manager of Anne Lock and Co, lent a building for the Buddhist Mission in Singapore as well as supporting the scheme financially; others who did so, in the context of a feast given to the pupils and parents of the school, were Tan Ban Hua of Tek Moh and Co., Heeme and Co., and "Mr Quay Gook Lin and the Chinese employees of Mansfield and Co.", this last suggesting a collective effort - or perhaps a tradition of community rather than individual dana - otherwise not in evidence in Dhammaloka's fundraising ${ }^{47}$.

A different kind of donor came from the old feudal classes of Burma. Thus the Saopha of Kengtung - a notable from the Burmese periphery, of a class which imported Europeans to teach their children and attended World's Fairs etc., funded Dhammaloka's travel from Singapore to Bangkok. Similarly, Mah Kin, widow of a minister of the deposed Burmese king and "one of the wealthiest Burmese ladies in Mandalay", gave a reception in Dhammaloka's honour to which hundreds of monks were invited. Elsewhere we have in Franck a claim that Dhammaloka had just been employed for 3 months by "the prince of Nepal" ${ }^{48}$.

Finally, Dhammaloka had occasional western sponsors. In J apan, he was supported by the Irish-Australian Theosophist Letitia J ephson 49, while a Times of Burma snippet reproduced in the Bangkok Times and Weekly Mail, notes that "some friends at the British Legation" had presented him with a marble clock - now stolen - for the school ${ }^{50}$.

If there is no very clear pattern here, it may be better to say that Dhammaloka appears to have been relying primarily on existing traditions of Buddhist dana (and western patronage) rather than building long-term relationships with political sponsors, though no doubt donors felt they were doing something useful as well as meritorious in supporting him, rather than other possible projects. An interesting, and as yet unanswered, question is whether his final departure from Singapore in 1905 - following an attack by the editor of the Straits Times - and his apparent departure from Burma in 1911 - following the failure of his appeal against sedition charges - may be because these events made it impossible for him to secure continued patronage for his organisation-founding activities.

\footnotetext{
${ }^{46}$ Alicia Turner, pers. comm.

${ }^{47}$ Straits Times May 2 1904, 5.

48 Alicia Turner pers. comm; Straits Times February 19 1903, 5; Burma Echo December 28 1907; Franck, Vagabond J ourney, 363.

${ }^{49}$ Gertrude Fisher, A Woman Alone in the Heart of J apan (LC Page, 201).

50 Presumably the point of this was not to recover the clock so much as to underline the status accrued by this particular gift.
}

16 


\section{Supporters and audiences}

Our first glimpse of Dhammaloka's supporters comes in accounts of his preaching in Mandalay in 1901. According to the Irish Sunday Independent,

Lord Curzon as viceroy in his tour of further India came to Mandalay in Upper Burma. To his party's astonishment, there was no-one at the railway station to greet him, with the exception of a few Government officials. There were no 'buses running from Ava to Mandalay, so to speak, to bring in crowds to greet Lord Curzon. The reason was not far to seek, for about a mile distant from the station nearly the entire population lined the road, tendering

\section{AN OVATION TO THE IRISH BUDDHIST}

of Rangoon, who was leaving their midst after a stay of several weeks.

Dhammaloka showed a newspaper clipping covering this same event to Harry Franck:

In it the reader was invited to compare the receptions tendered Lord Curzon and the Irish Buddhist in Mandalay. The viceroy, in spite of months of preparation for his visit, had been received coldly by all but the government officials. Damalaku had been welcomed by the entire population, and had walked from the landing stage to the monastery, nearly a half-mile distant, on a roadway carpeted with the hair of the female inhabitants, who knelt in two rows, foreheads to the ground, on either side of the route, with their tresses spread out over it ${ }^{51}$.

Dhammaloka led at least three such preaching tours across Burma (1900-1, 1908, 1910). Such scenes were standard for celebrity preachers: Turner notes

The most popular itinerant preachers arrived in towns and drew enormous crowds. They took over the largest venues to deliver their sermons for three or four nights. Those trying to hear the monks would overwhelm all the means of transportation in these towns, creating brief economic booms and headaches for colonial officials in charge of the area. There are reports of overfull trains, steamers, bullock carts and carriages coming to hear preachers... U Dhammaloka was said to have drawn thousands to the small town of Meiktila [in 1908]. (Turner 2009: 205 - 6).

The sedition charge brought against Dhammaloka in 1910 relied on his having delivered three addresses "to large Burmese audiences at Moulmein" earlier that year; one of these audiences is specified as being "from 1,000 to 2,000 Burmese". He told American freethinkers that he had spoken on Thomas Paine "to an audience of about five thousand at a town in Upper Burmah" 52 .

Thus one picture of his Burmese audiences, particularly outside Rangoon, should be that of large crowds, addressed through an interpreter, perhaps the target for the distribution of tracts, and making suitable offerings. No doubt this in turn relied on invitations from local monks or lay organisations such as the Society for Promoting Buddhism ${ }^{53}$.

\section{A second image can be gleaned from reports of the ordination of MT de la Courneuve at} Dhammaloka's Singapore mission in 1904:

When everyone had been seated, including about one hundred little Chinese boys belonging to the School attached to the Mission, the Lord Abbot the Right Rev. U. Dhammaloka took his seat opposite the

\footnotetext{
51 Sunday Independent August 6 1911: 8; Franck, Vagabond J ourney, 364.

52 Criminal Law J ournal of India vol. 12, 1911, 249; J ohn Remsburg, Thomas Paine: The Apostle of Liberty (New York: Truth Seeker, 1917, 192).
}

53 See Alicia Turner's article. 
audience. The Rev. Ocha, head of the Japanese mission in Singapore, whose premises are in Serangoon Road, sat on the Abbot's right hand, being the next senior Priest. U. Dhammawanga, a novice (Samenara), who is a Welshman by birth, and speaks with an American accent, sat on the left of U. Dhammaloka. Dead silence prevailed for a few moments and the choir of the Buddhist Mission, led by the Abbot, then sang a chant of praise in English. The little Chinese youths showed that they had been well taught and their shrill little voices made the echoes ring with their hymn of praise...

\section{The Novice's Prayer}

The novice, M. T. de la Courne[u]ve, a European whose father is said to be a Deputy Commissioner of the Burmah Civil Service, then walked into the hall from an inner room. He is a short, well built young man of good appearance and was neatly dressed in a black suit of European cut. If it were not for the fact that his head was shaved as bald as a trout he might easily have been mistaken for one of the European guests. The candidate, we understand, was until quite recently an Inspector of Police in Pahang, but relinquished his position in the Government service to join the Holy Brotherhood. On entering the room he knelt down and bowed his head to the ground three times in front of the alter [sic] on which was placed a small Siamese statue of Buddha made of gilt marble. It was indeed a strange sight to behold a European bowing down to a graven image, and a thrill of astonishment passed through the Europeans present, who had never dreamed such a thing possible. The candidate then prostrated himself before U. Dhammaloka and repeated after him in Pali the ordination service. This lasted about half an hour and a yellow robe was then handed to him. He retired to an inner recess to don his robes while the choir sang another chant of praise ${ }^{54}$.

Here we have a second kind of audience - perhaps made possible by the first, mass support - a combination of other ordained Buddhists (Ocha and Dhammawanga), a disciple (de la Courneuve), dependents (the schoolboys), and no doubt some of his Singaporean patrons as well as the journalist and other non-Buddhist observers - and a different kind of event: ritual rather than public speaking.

Other, sketchier, accounts by missionaries give a sense of his popularity around Burma, as do some of Franck's stories ${ }^{5}$. These latter include Dhammaloka's ability to help Franck and companions jump a train through his prior friendship with a station policeman at Calcutta whom he had met in Singapore, his ability to arrange for them to stay in a monastery in Chittagong and later in Rangoon; and the reaction of a Burmese border guard, for whom the name of Dhammaloka is enough to let Franck and companions through. The passage quoted at the end of this article also shows a Burmese crowd as an appreciative audience for Dhammaloka's besting of an Indian Christian missionary in debate.

Of course such participation should not be interpreted as organisational membership, but it does imply something beyond idle curiosity: a sense of the speaker's Buddhist integrity, a desire to see what one's money is being spent on, an interest in the Buddhist revival, concern at this new anti-Christian threat, enthusiasm for someone known to be a lively performer, and so on - all in all, a reputation which was a ready-made resource for new initiatives.

\footnotetext{
54 Straits Times, October 3 1904, 5.

${ }^{55}$ Franck, Vagabond J ourney, 360 - 420.
} 


\section{Controversy}

Franck's tale of Dhammaloka and the Indian missionary brings us neatly onto the subject of controversy. His writing is nothing if not polemical, and this was clearly also true for his face-to-face encounters:

He had shut up no less than three mission stations, he told us, mainly by force of public argument, and he gave us details of one polemical struggle in which the missionary was fairly routed in the eyes of the audience, because he was unable to produce "anny sort of proof" for the story of J oshua and the sun..."If anny one gives you throuble on these subjects," said he, "just you refer him to me. I don't think there'll be much more anxiety for public controversy so long as I'm around." 56

Dhammaloka was both a good debater and a man for public confrontation, as in the "shoe incident" which sparked his first court appearance. The background to this was Burmese Buddhist opposition to the wearing of shoes at pagodas, not primarily on the part of Europeans (who wore them all the time) but on that of Indian police officers (who would have removed them while off-duty at Hindu shrines). Dhammaloka publicly confronted an off-duty Indian policeman at a festival at the Shwedagon pagoda in March 1901 over the issue, who in turn filed a report. His timing was good: he was supported by the Dhammathawana Association and imitated by another monk in Mandalay. Government attempts to get the pagoda's trustees to disavow Dhammaloka were refused, though the broader issue was eventually defused for a while ${ }^{57}$.

Dhammaloka's second (known) brush with the law came off rather differently. Following three sermons at Moulmein in October - November 1910, he was charged with sedition, specifically with attempting to promote enmity between Christians and Buddhists, on the instance of some local Christian missionaries. In J anuary 1911 the sentence - being bound over to keep the peace - was upheld ${ }^{58}$.

From a social movements point of view, two obvious questions arise. Firstly, a minor conviction - particularly one with no actual penalty (presuming that sureties could have been found) is typically a gift from the authorities to a vocal opponent, rather than an effective means of silencing them; and Dhammaloka was not a man to be easily scared. In fact he highlighted the case in correspondence with the American Truth Seeker and the Humanitarian Review.

Secondly, the views which he is said to have expressed are not obviously different from those which by this point he had committed to paper (and which had been reproduced in the national English-language dailies) many times; while this makes it clear that the prosecution was at some level a political decision rather than an automatic result of his statements, it does not explain why such a prosecution had not happened several years previously.

\footnotetext{
56 Cotes, "Ordination of Asoka", 759.

${ }^{57}$ Alicia Turner, Buddhism, Colonialism and the Boundaries of Religion: Theravada Buddhism in Burma 1885-1920 (PhD dissertation, University of Chicago, 2009, 261- 262).

58 Criminal Law J ournal of India vol. 12, 1911, 248 - 250; Donogh, History and Law of Sedition, 215 - 6; Purser, Christian Missions in Burma, 218, Macdonald, Fifty Years of Freethought, 372.
} 
This obviously raises all sorts of possibilities which are currently being researched; what can be said with some certainty is that Dhammaloka disappeared from public view in 1911, probably leaving Burma for good.

\section{Organisational sustainability}

Why was Dhammaloka so good at founding organisations, and so bad at keeping them going? There is no doubt that in Weberian terms, Dhammaloka falls under the heading of a charismatic authority: one who breaks with established patterns of behaviour and creates new ways of doing things 59 . In many ways, his claim to be doing something new (e.g. founding a free school), to be the first (e.g. the first European bhikkhu) and so on was part of his "stock in trade". At the same time, Dhammaloka lacked his Saint Paul, a follower capable of "routinising his charisma" and building what we would now call organisational sustainability: few if any of his organisations seem to have survived him. Put another way, despite the evident presence of supporters and even ordained disciples, he does not seem to have trained or encouraged them to take up his lead and finish what he had started.

As noted above, this may in part be a result of "funding structures"; building a new monastery or pagoda is understood as more meritorious (not to say prestigious) than refurbishing an old one, and other Southeast Asian Buddhists traditionally accuse the Burmese of being particularly prone to starting organisations with no visible result ${ }^{60}$. It may also have been an effect of the natural celebrity focus on extraordinary monks - who if they did not ordain strong lineages of disciples or establish new monasteries were unlikely to leave much of a legacy after their deaths. Dhammaloka also does not seem to have seen organisation-building as a necessary goal; the impression from his writings is rather that what he felt was needed was simply a reaffirmation of Buddhist identity and a rejection of Christian missionaries - neither of which necessitated a new organisation.

\section{Dhammaloka's organising style}

This fits with the suggestion made earlier that Dhammaloka was not so much a long-term organisation-builder, concerned with the survival of his projects, the preservation of his legacy or the development of an effective organisation and independent fund-raising capacity, as he was a "social movement entrepreneur", in the language of social movement studies, someone who conjures up a movement, or at least an organisation, through the successful development of "frames" justifying action - in his case, the neat alignment of Buddhism, opposition to missionary activity, freethought and temperance. In this sense, his work was opportunistic (most obviously in relation to funding), widely scattered geographically (particularly Singapore, Siam and Burma) and more concerned to "raise awareness" than to "build" - or, in the language of his day, to agitate and educate rather than to organise. Awareness, however, he certainly did raise.

\footnotetext{
${ }^{59}$ Max Weber, Soziologische Grundbegriffe (Stuttgart: LTB, 1984).

60 Alicia Turner, pers. comm.
} 
It follows from this that the main reason for his disappearance from subsequent histories of early western Buddhism and the Buddhist Revival is (in a sense) self-inflicted: he did not figure in the organisational genealogies of those who came to write the history, because he did not place as much emphasis on organisational sustainability as (say) Ananda Metteyya. This fact which no doubt also accounts for the absence of a "Dhammaloka archive" of correspondence: he simply carried a notebook of press clippings around with him, very different from the bursting cupboards in the London Buddhist Society which now hold the records of the Buddhist Society of Great Britain and Ireland.

Despite these criticisms, Dhammaloka was remarkably effective over the eleven years of his life (1900 - 1911) which we have reasonably certain evidence for. Few activists, and come to that few Buddhist teachers, are able to do as much as this in a decade if starting from scratch, which raises the obvious question of what he had been doing before coming to the attention of the English-language press, somewhere in his fifties.

The easiest answer is the one he gave himself: that he had in fact been an ordained Buddhist for some considerable length of time before 1900, perhaps for one or two decades, and had experience being both travelling preacher and monastery schoolmaster. It is quite a leap, however, from these activities to his international Buddhist activism, and it is hard to take this as the full story.

Had he learned to organise from other figures in the Buddhist Revival, from the Maha Bodhi Society, or perhaps from the Theosophicals? Should we look for the sources of his organising know-how in an Irish context, or perhaps more plausibly in Irish diaspora politics in the UK and US? Cotes drew precisely this parallel:

He spoke slowly, with his fingers joined at the tips, and at the end of every sentence he swayed forward on his toes and back - he might have been a ward politician addressing a crowd in the interests of Tammany (1902: 758).

Or should we instead look further left - in American trade unionism, or the networks of organised freethinkers? In terms of organising "style", this last possibility seems to come closest, although there is a frustrating lack of material to give us the answers we need. As noted, however, his main goal was never to build organisations of the Tammany Hall type, and indeed those he did build had nothing of the formality or durability of Theosophical or Maha Bodhi societies. Nor, as a monk, did he necessarily need quite the same organisational solidity that the laymen and women of the Buddhist revival needed for their organisations.

Rather than the firm organisational structures and concern with stability that characterised, say, Irish ethnic politics in the US or the new wave of socialist and mass union activity in Europe from the 1880s onwards, the loose personal networks, fluid organisations and personal mobility of his style fit better with "hobo" migrant workers and their organising styles in the US, the anarchist traditions of the day, and the free thought networks that we know he was involved in - in all of which agitation and education were easier than long-term organising, and for many of whose proponents the goal was not so much to build power as (in today's terms) to resist it.

Certainly, an organising ability like Dhammaloka's is not simply invented on the back of an envelope; it is in some way learnt, whether in a particular organisation, a particular 
movement culture, or in some other way. In other words, if organising skill can only give us very general indicators as to his past, another avenue is to explore that aspect of his known activities which is perhaps most likely to point back before his time in Asia: his connections with western, plebeian freethought.

\section{II) Dhammaloka and plebeian freethought}

Organising style, then, can take us so far, but with little certainty. This section tries a rather different approach, in terms of his known intellectual affinities, and thus also his role in attempting to import a particular frame to the Buddhist revival. What, if anything, did he bring to this latter as a working-class freethinker? And what indications do we have of where he got it from?

To set the scene, here is his own profession of (un-) belief, a 1910 open letter inserted into The teachings of J esus not adapted to modern civilization, which is worth quoting in full ${ }^{61}$ :

\section{A WICKED PROCLAMATION. TO HIS FELLOW BEINGS FROM THE SINNER IN CHARGE OF THE BUDDHIST TRACT SOCIETY}

An alleged wicked Society - wicked for reason that it has few principles and scarce a politic. Most Societies, like the Y. M. B. A., and [Ananda Metteyya's] late International Buddhist Society are loaded to the guards with high sounding titles, principles, platforms and politics. But the Buddhist Tract Society by heaving most of these over-board is enabled to teach

Goodness without a God,

Happiness without a heaven,

Salvation without a Saviour,

And redemption without a Redeemer.

It is thus the only great Society in the great East that is able to run without a God or Devil or "Ghost." The Buddhist Tract Society is full of human sympathies; but as none of these are wasted upon the "Saviours" and "Gods." It has an abundance for the beings of earth.

\footnotetext{
${ }^{61}$ Anon. (George W Brown?), The Teachings of J esus not Adapted to Modern Civilization. Rangoon: Buddhist Tract Society, 1910
} 
People who weep over the sufferings of the alleged "Saviour" seldom weep much of suffering man, except he be nude and in Africa, without a bottle of "Guiding Star brandy," a "Holy bible" or "Gatling-gun."

The Buddhist Tract Society is warmly attached to life and the beauty and happiness that attend it: yet it is a firm believer in the doctrine of Reincarnation.

The Buddhist Tract Society fails to see the necessity of a vast host of able-bodied, well-fed Sky-pilots managers of matters between men and the big Papa in the Clouds, and it holds if a man's soul is to [be] saved by man's work, the man that has the soul has got to do the work.

The Buddhist Tract Society believes the men of a nation ought to take care of, support and protect the women and children of that nation and that such men as oppress, kidnap, and abuse those ought to be jailed or otherwise disposed of ${ }^{62}$.

The Buddhist Tract Society has but faint love for Police Inspectors that kidnap "J apanese Women" or "Good Templars" that harbours such wretches in their lodges, or boys who stone birds, disobey their parents or lack respect for the aged.

The Buddhist Tract Society has pity for the victims of misplaced confidence - such as the members of the "Guiding Star" [temperance] lodge, I.O.G.T., and the feeble-minded Christian Sky-pilots and priests that, rolling their hypocritical eyes upward, implored vacuity and nothingness to feed and clothe them and confound their enemies. The "Irreverent" general President of the Buddhist Tract Society is paying five rupees (Rs. 5) a head for ghosts, little or big, old or young, male, or female, holy or unholy, and he wants all he can get. He is also paying fifteen thousands rupees (Rs. 15,000) a head for virgin mothers. He has furthermore a standing offer of fifteen million rupees, (to be paid in job work and advertising-terms cash) for one sane man who will swear he believes there once existed a triple-headed god - a father who was his own son, Christ, a son Christ, who was his own father, god, and a ghost that was both father and son, yet distinct from either, and that these three were at once the "heavenly father," the "son of man," and the "holy ghost" the three being one and the one: three.

Let one sane Christian-sky-pilot swear he believes this stuff and get the reward.

In writing for membership to the Buddhist Tract Society enclose Rs. 2 and state your age and sex. If you have religion to fall back on when you cheat your neighbour or receive a gold medal for kidnappingJ apanese Women, say so. Also if you have an immortal soul, say so like a man, and state if you ever received a gold medal from the "Guiding Star" lodge, No. XI., I. O. G. T., for kidnapping a J apanese Woman a few, years ago, say so, and state if your soul has ever been of any use to you and the other Good Templars [IOGT] about you. If you haven't an immortal soul, (and the chances are that you haven't) the Buddhist Tract Society will help you to get along and be useful and good without one.

Revised at the Buddhist Tract Society Headquarters, in the City of Rangoon and the Province of Burma, on the 1st day of J uly, in the 1910 year of Christian computation, by-

\footnotetext{
62 This and following paragraphs pick up a charge levelled by Dhammaloka at a temperance lodge in Rangoon.
} 
the-way, is based upon an alleged event that never happened, or if it did, it is uncertain when, and, in any event, it was of no sort of consequence, and therefore, being a starting point for "Christian Superstition," only ought now to be discarded.

REVD. U. DHAMMALOKA,

President of the Buddhist Tract Society

\section{Freethought connections}

Where did this wonderfully idiosyncratic mixture of Buddhist identity, irreverent freethought and temperance lodge polemics come from? While there are lots of possibilities, at present there is solid evidence only for two trails. One is his correspondence with American freethinking periodicals, the other the contents of the Buddhist Tract Society pamphlets. Between them they give some indication of the nature of Dhammaloka's links to western freethought, but (as we shall see) prove frustratingly little.

\section{Freethinking correspondence}

In the period 1908 - 1911, Dhammaloka was in direct correspondence with at least three leading freethinking periodicals in the US: the New York Truth Seeker, the Los Angeles Humanitarian Review and the Kentucky Blue-grass blade. The Blade (1884 - 1910) was one of the first freethought journals in the US and was widely circulated, as well as persecuted: its founder Charles Moore was twice jailed for blasphemy (the second time receiving a presidential pardon) and supported a range of other liberal-radical causes.

As noted, Dhammaloka was an indefatigable correspondent of the American press, and this presumably explains why the Blade had sent him a copy on spec. Dhammaloka replied to this enclosing a subscription, and commenting

I was wondering how you got my address, as I did not think that we "heathens" in Burma should attract attention from any person of intelligence, except the "holy and sanctified" Christian missionary"... I like the motto of your paper. I trust that you will always carry it out in spirit as well as in letter. With best wishes and long life to every champion of Freethought...63

In the same issue the Blade published another letter of Dhammaloka's addressed to the secretary of the Paine Memorial and Historical Association, J ames Elliott. It is worth quoting at length:

You ask if there are 2,000 admirers of Thomas Paine in Burma. Yes, and double as many. There were sold in Burma over 10,000 copies of the "Age of Reason" last year, as well as some copies of the "Rights of Man".

I trust this year that we shall do better than last year. You will convey the greetings of ten millions of Buddhists of this province to your Association on the occasion of the great celebration of that grand Hero of Freethought. I am making the necessary arrangements to celebrate the occasion on a grand scale...

63 U Dhammaloka, "From far-off India". Blue-grass blade, December 12 1909, 6 - 7. 
We have not translated any parts of the "Age of Reason" as yet, but our Society intends to do this work next year, and you shall receive a copy of the same. We are going to bring it out in three parts, and if the funds permit we shall bring it out in full.

I am sure that every friend of Truth will agree with me that it is time that we should show the bigots and the ministers of every church that Thomas Paine was the real friend of man - in fact, we can call him a Humanitarian of the loftiest type ${ }^{64}$.

Around this same period Dhammaloka was also writing for the Truth Seeker. The J une 27, 1908 issue included "Buddhism misrepresented by Christian missionaries by Rev. U. Dhammaloka", and he also contributed a "fugitive piece" in 190965, after one by Ben Reitman, who had been Emma Goldman's partner. In 1911, the Truth Seeker noted his conviction for blasphemy in terms its editor George MacDonald later summarised as follows:

On complaint of two Christian missionaries in Moulmein, one hundred and seventy-five miles from Rangoon, Burma, the local authorities brought to trial for blasphemy the Buddhist monk U. Dhammaloka, who, besides defending Buddhism, organized the Burma Freethought Association and made an aggressive fight against Christianity and the Bible. The court held him under substantial bonds "to keep the peace" or for "good behavior."

MacDonald also noted Harry Franck's encounter with Dhammaloka, quoting Dhammaloka from A vagabond's journey around the world as saying that "J aysus Christ was the biggest faker that the world ever saw or didn't see"66.

Thirdly, Dhammaloka wrote to the Los Angeles-based Humanitarian Review (August 1910, vol. 9, 50767) ordering tracts and sending a subscription for 1911, commending it on the previous year's output and wishing that "you be spared many years to carry on the work of freeing the minds of the orthodox".

We can also note that the BTS' Buddhism: the highest religion included ads for the Truth Seeker as well as the New Zealand-based Examiner ("An advocate of rational thought and philosophy, science and religion") and GW Foote's Freethinker, based in Newcastle, England ${ }^{68}$. For the period 1908 - 1911, then, we have glimpses of a fairly active two-way relationship between Dhammaloka and freethinking journals, both parties evidently approving of the other's position in each case. Westerners were no doubt happy to have a Buddhist voice to use against Christianity, and Dhammaloka's comments make it clear that he understood not only himself but Buddhism as such as aligned with free thought. There is, however, no evident preference for one kind of free thought over another in these connections.

\footnotetext{
64 U Dhammaloka, "A Hindu [sic] on Paine". Blue-grass Blade, December 12 1909, 7.

65 Macdonald, Fifty Years of Freethought, 335.

66 Macdonald, Fifty Years of Freethought, 372 - 3.

67 The dating is confusing here, but as the letter, dated Jan 4, mentions the trial it must have been sent in J anuary 1911, and the August 1910 date is wishful thinking on the part of the editor - who was to retire the following year, aged 70 .

68 There are also various mentions of Dhammaloka in other western freethinking publications, but which do not necessarily demonstrate direct personal contact, such as the Freie Wort's translation of his Akyab declaration.
} 
The period 1908 - 1911 also corresponds, of course, with the floruit of the Buddhist Tract Society and hence Dhammaloka's use of western freethinking texts, to which I now turn in search of a clearer sense of his particular orientations.

\section{Buddhist Tract Society publications}

Section I used the BTS as one of the best documents of Dhammaloka's organising work. The BTS tracts, however, should in principle also be a good source for the kinds of traditions he aligned himself with - although, as we shall see, the answer is at best "highly eclectic". The dates given below are for the various BTS editions of the texts in question.

\section{Thomas Paine (1908-9)}

As we have seen, the BTS claimed to have distributed, if not published, the Rights of Man and Age of reason in 1908, and to be working on a three-part translation of the Age of reason. Paine was one of the classic points of reference for freethinking perspectives, particularly radical ones: and (in part as a result of the passage of time) was attractive to deists, anti-clericals and atheists alike. Geographically, too, his influence was widely felt; a reference to Paine can point as easily to Ireland, Britain or the US - or, indeed, rural Burma. We have just seen the sales figures Dhammaloka claimed for Paine; elsewhere he wrote

The Buddhist Tract Society of Burmah observed the one hundredth anniversary of the death of Thomas Paine [in 1909]. We had large audiences. I myself spoke to an audience of about five thousand at a town in Upper Burmah ${ }^{69}$.

\section{Anonymous (1909)}

In 1909 the BTS brought out Bible atrocities and immoralities in Burmese (but with an English title); to date we have not identified the source of what may in any case have been an epitome of many pre-existing freethinking collections along these lines. It is, however, safe to say that this approach was particularly characteristic of freethinkers in Protestant countries, where the main target was the Bible rather than the behaviour of priests (although we know that the latter was a favourite theme of Dhammaloka as preacher).

\section{Sophie / Sophia Egoroff (1909)}

In 1909 the BTS brought out Sophia Egoroff's Buddhism: the highest religion. Egoroff was a Russian artist of some ability, whose paintings of the Buddha were exhibited at the Musée Guimet around 1908. In 1906 or 1907 she had brought out a life of the Buddha in

69 Quoted in Remsburg, Thomas Paine, 192. 
French (published at Lucern); this was translated in 1910 (perhaps by the BTS?) as Buddha-Sakya-Muni: a historical personage who lived towards BC 390 - 320.

The 1909 BTS volume may well have been an original commission, arising from the 1908 trip to India she mentions in Buddha-Sakya-Muni. It seems likely that she met Dhammaloka, whether in present-day India or Burma, on this visit. Certainly both he and she associated Buddhism with freethought, and she brought an element of class critique into her perspective. The dedication reads

Long live humanity pushed forward by a new torrent of social ideas towards peace, fraternity, equality and civilization. Let Buddha Sakya Muni be remembered and honored as divine socialist...

The text consciously aligns Buddhism and free thought:

Buddhism preaches that we must make all possible effort towards knowledge, to look at ignorance as an enemy, and to fight it always and everywhere with the weapon of science and Freethought.

Egoroff brings a lightly feminist perspective which is otherwise absent in the BTS' work. Her list of the "highest men" who have "shown respect to women" runs as follows:

Buddha, Thomas Paine, [American freethinker] Robert G. Ingersoll, [British freethinker] Charles Bradlaugh, Leonardo da Vinci, Berthelot, the French scientist, and other scientists and artists.

The first four items of this list neatly tally with Dhammaloka's own perspective, and combining these various links one wonders whether the two may not have learned from each other at this time. Along with freethought, science and respect for women, her text also highlights temperance, and the BTS' "preaching against Opium, Alcoholic drink, Morphia, Ganga and Cocaine" - again suggesting that there was a personal connection and that the text may have been commissioned, unless this was an interpolation by Dhammaloka ${ }^{70}$.

\section{George W Brown (1910)}

In 1910 the BTS published The teachings of J esus not adapted to modern civilisation, probably a reprint or epitome of George W Brown's text of the same name, which was subtitled "with the true character of Mary Magdalene" 71 . Brown's text, self-published in Rockford, Illinois, had first been published in 1891, with a third edition in 1902. Such a text was presumably fairly rare by 1910, suggesting a more direct personal connection or the handing on of a physical copy, perhaps in the context of the highly sociable free thought contexts discussed in section III.

The BTS version seems (we have not been able to compare the two) to include various interpolations by Dhammaloka, for example on the politics of temperance lodges in Rangoon ${ }^{72}$. One of these interpolations uses the term "sky-pilots" for missionaries, a term

\footnotetext{
70 Sophia Egoroff, Buddhism: the Highest Religion (Rangoon: Burma Echo Press / BTS, 1909, 3, 13).

${ }^{71}$ This is made almost certain by a reference on p. 2 to Researches in Oriental History, another title of Brown's.

${ }^{72}$ P. 36 claims authorship of The Bible God Disproved by Nature, suggesting that Dhammaloka shared the $19^{\text {th }}$ century's rather lax attitudes to plagiarism.
} 
particularly associated with sailors at the time (according to the OED), and found elsewhere in Dhammaloka's writings. Another such interpolation is a satirical "hymn" by Dhammaloka, supposedly singable to the tune of Auld lang syne:

\section{The Christian life: pardon for Rangoon parsons}

Speak no more of priestly foible,

Publish not the Parson's Crime;

For on Sunday hard we labour,

Lead a Christian life sublime.

Though we kiss the maid and matron,

Warm embrace them every day,

God will know the sore temptation,

And will wash our sins away!

Tell it not we lie and slander,

Vilify and base defame;

For we serve the Lord J ehovah,

Do it all in J esus' name.

Though in lies and lust we revel,

Yet we solemn preach and pray;

So the blood of Christ, the Saviour,

Washeth all our guilt away!

Call us not a gang of Humbugs,

Whom the money-lords can buy;

For we safe and sanely pilot

Souls to heaven in the sky.

So laborious our profession,

Now and then we must be gay;

But the Lord will freely pardon

Washing all our sins away!

Fans of Robert Burns will recognise echoes of "Holy Willie's Prayer (Address to the Unco Guid)", and more generally the flavour of working-class attacks on religious hypocrisy. 
This sense of the importance of religion as moral performance, as Alicia Turner's article notes, was central to Dhammaloka's personal practice, and is evident throughout both his temperance work and his attacks on missionaries.

Interpolations aside, the rest of the text covers themes which are far less characteristic of Dhammaloka: an attack on Christianity for approving of beggary and dependence on the community (which would be strange for an ex-hobo and Buddhist monk) and for criticising wealth, for example. Brown was in this sense a representative of the more middle-class, liberal and "Protestant" tendencies in freethought - and at some distance from, for example, Egoroff's divine socialism.

\section{Anon. The Famous Decree}

The endpapers of The teachings of J esus... advertise the next BTS tract as follows:

Famous and infamous decree of the Roman Catholic Council passed at the Lateran, Rome, A.D. 1215, in the original Latin with translation in parallel columns, and with full explanation of its meaning and its results in Europe and Asia. The foundation of the Holy Inquisition.

This will appear as our next publication ${ }^{73}$.

Unlike other BTS texts, this is clearly a specifically anti-Catholic tract, contrasting with (say) the tone of Bible atrocities and immoralities. We can safely assume that Dhammaloka's education did not run to translations of medieval Latin, and it is unlikely that the BTS would have commissioned such a piece, but to date we have not identified the original.

\section{Wm Emmette Coleman (by 1910)}

The missionary Francis Clark writes

The Bible God disproved by nature is the title of one of [the BTS'] tracts, which may serve as a sample of all its literature. It is a booklet of forty-eight pages bound in pink paper and sold for only one anna, or 3 cents, and is printed in English, evidently to counteract the baleful teaching of the missionaries from America and Great Britain.

Clark, probably mistakenly, ascribes the text in toto to Dhammaloka, and summarises it as follows:

the Rational, Philosophical Freethinkers and Buddhists entirely ignore his [the Christian God's] existence...

Like The teachings of J esus... this text too included poetry (this much at least interpolated by Dhammaloka):

he "drops into poetry" at times, and turns his rhythmical guns against the "sky pilots," as he facetiously calls the missionaries.

${ }^{73}$ Anon., The Teachings of J esus..., 64. 
Clark notes that Christianity was targeted as being unscientific (the six-day creation story came in for particular scorn, as did J oshua at the walls of J ericho) but also as unethical:

Of all the cruel, bloodthirsty, sanguinary, malignant, ferocious, diabolical, and infernal fiends and monsters of which the human mind ever conceived, the Bible God is the most devilish and diabolical... Were it possible for such a despicable fiend to exist, no language would be capable of depicting the utter loathing and contempt such a wretch would necessarily inspire in all men and women of kindly sympathies and generous impulses.

Presumably this passage followed a selection of "Bible atrocities and immoralities". Clark concluded:

["This outbreak"] shows that education is not always an ally of Christianity in missionary lands. Mr. Dhammaloka's excellent English education has only made it possible for him to be more vituperative in his abuse of Christ and Christianity, for I have not quoted his most blasphemous words about Christ Himself 74 .

In this case at least, the "excellent English education" was probably that of William Emmette Coleman, who had published a tract of this name a third of a century previously ${ }^{75}$. Coleman's scholarly image was no doubt part of the reason for the BTS' section of this text, though it was as often deployed against Theosophists as against Christians.

A member of the American Oriental Society, Coleman defended "American Spiritualism" against "Sclavonic Theosophy" on academic grounds, in texts such as "Unveiling of Isis unveiled" and "Mrs. Besant and Indian civilization"76:

outraged by Madame Blavatsky's pretensions to Oriental learning, [he] undertook a complete exegesis of her works.... showed that her main sources were H. H. Wilson's translation of the Vishnu Purana; Alexander Winchell's World Life; or, Comparative Geology; Donnelly's Atlantis; and other contemporary scientific and occult works, plagiarized without credit and used in a blundering manner that showed but skin-deep acquaintance with the subjects under discussion ${ }^{77}$.

Such attacks worried William Quan J udge, Irish-born head of the American Society, who

followed up the articles mentioned by publishing an editorial in the "Path" for J uly, 1893, with the significant title, "A Plot Against the Theosophical Society." Primarily this was drawn up as a warning concerning a renewed series of attacks on H.P.B. by certain enemies outside the Society (W. Emmette Coleman and Vv. Solovyoff, although not mentioned by name)...78

As we shall see below, a defence of spiritualism was by no means incompatible with aggressive commitments to freethought, though in this case it seems likely that the main attraction of Coleman's text was the effective projection of intellectual authority that Clark complained of.

\footnotetext{
74 Clark, "Buddhism on the warpath", 247 - 8.

75 Published by DM Coleman in New York in 1875, Coleman's tract was 39 pages long, and would have fit neatly in the BTS series.

${ }_{76}$ Published respectively in The Golden Way 1891 and Light XIV, April 141894.

${ }^{77}$ L. Sprague de Camp, Lost Continents: the Atlantis Theme in History, Science and Literature (New York: Dover, revised edition 1970, 54 - 58).

78 Anon., "The Theosophical Movement" (part 29 of 34), Theosophy 10 no. 7, 1922.
} 


\section{Robert Blatchford ["Nunquam" of The Clarion] (pre-1914)}

Purser noted of Dhammaloka that "He has epitomized some of Mr Blatchford's antiChristian literature and has had it translated into Burmese" 79 . Blatchford was a British socialist and columnist for the popular Clarion, whose freethinking works included titles such as Christians and infidels (1907), God and my neighbour (1907), etc. Here we are in a very different territory to relatively obscure figures such as Coleman or Brown: like Remsburg (below), Blatchford was immensely popular and very widely circulated. Without as yet knowing the details of the Blatchford epitome, we can safely assume that it had a far stronger sense of class antagonism to Christianity than either the pro-capitalist Brown or the scholarly Coleman, and that its target was mainstream Anglicanism rather than Catholicism.

\section{J ohn Remsburg (no date)}

As president of the BTS, Dhammaloka was quoted as writing "I have asked a bookseller to order twenty copies of Remsburg's work"; we do not know whether this led to any republication ${ }^{80}$. Remsburg, a secularist writer and indefatigable travelling lecturer (he is said to have delivered 3,000 lectures) was very much a man after Dhammaloka's heart ${ }^{81}$. His publications were extensive, including Life of Thomas Paine (1880), The image breaker (1882), False claims (1883), Bible morals (1884), Sabbath breaking (1885), and The Bible (1903).

\section{An eclectic collection}

These titles do not exhaust the BTS' publications: we know that the BTS were already printing texts in 1907 (claiming a hundred titles for that year alone) and distributing them at missionary meetings in 1908 (when they seem to have been particularly active), but before we have any record of what their content may have been.

What they do make clear is that, like his correspondence, his publishing activities do not suggest any neat alignment of Dhammaloka with a particular tendency within freethought

\footnotetext{
79 Purser, Christian missions in Burma, 217.

80 Ingalls, History of Atchison County, 506.

${ }^{81}$ Atchison County, Kansas, to which Remsburg moved from Ohio in 1868 and which from then on he used as a base for his freethinking activities, was also the target of a radical plebeian attempt to create a co-operative colony in 1869 (Stan Shipley, Club life and Socialism in mid-Victorian London. Oxford: History Workshop, 1971, 80 - 83). Five or six hundred people saw the first pioneering party off, and for the next five years it was to be a major focus of the "Soho O'Brienites", a group of plebeian radicals who formed a long-term historic link between the Chartist politics of the 1840s and the socialist politics of the 1870s and 1880s (Megan Davies and Keith Flett, "The Tenacity of Activism?" Paper to 14th international Alternative Futures and Popular Protest conference, Manchester Metropolitan University, 2009; Shipley, Club life). There was probably some connection between the two, almost simultaneous moves.
} 
or even a particular country's traditions, beyond the most obvious points: that his continental European and non-Anglophone connections are few, and that American freethinkers are somewhat better represented than others.

In terms of intellectual content, the BTS tracts are an eclectic collection, which range from "divine socialism" to the defence of capital accumulation and from attacks on the Bible characteristic of Protestant countries to critiques of Catholicism. Arguments are based sometimes on science and sometimes on common sense, sometimes on economic utility and sometimes on political implications, sometimes on textual criticism and sometimes on morality. The authors write in both scholarly and plebeian tones and are American, British and Russian; their texts are sometimes commissioned, sometimes republished with interpolations, and sometimes summarised ${ }^{82}$.

The series implies fairly wide reading: as noted, some of the republished texts, like Coleman or Brown, were presumably fairly obscure, while others, such as Blatchford and Remsburg, were "big names" in the free thought of the day. We have seen that Dhammaloka regularly ordered in pamphlets and subscribed to freethinking magazines; he could also draw on classics like Tom Paine and (apparently) commission relatively wellknown figures like Egoroff.

The costs involved must have been fairly substantial, even if the BTS did not literally publish a hundred different titles at a time; quite apart from printing costs and the practicalities of distribution, Dhammaloka was furiously editing and interpolating, someone was translating into Burmese, and authors may have been commissioned.

The implication of all of this is that eclecticism was a choice, not a product of scarcity. That Dhammaloka did not feel a need to produce texts which only represented one single "line" or type of freethought - is itself a kind of information. If so, the search for an intellectual "lineage" or "tradition" in which to locate Dhammaloka is a dead end, and perhaps because it is the wrong sort of question.

What we see in these texts is certainly an indication as to his own intellectual culture, but suggests that that culture was not one of loyalty to a particular line or organisation, but rather an autodidact one, without any orthodox "theology" of freethought, any single target or line of argument. This in turn produces a different question: where, in this period, might we look to find such self-taught, widely-read but unsystematic freethinkers?

\section{III) The cultures of plebeian free thought: where did Dhammaloka learn his trade?}

Thus far, the search for the early Dhammaloka has shown two things. Firstly, his achievements in Asia between 1900 and 1911 were substantial, not least given his age and

\footnotetext{
82 This very eclecticism might on one reading suggest that the works we know are a relatively small proportion of the total BTS production.
} 
background. We find a major agitating presence, a significant practical contribution to the Buddhist Revival at least as effective as that of many of his contemporaries, and an interesting encounter between western freethought and Asian Buddhism. Secondly, however, we fall short on specifics which could help us identify the background that made this possible, and one reason for this is that trying to "place" him as belonging to a particular organising or intellectual tradition is to treat him as too much a product of his education or training and to underestimate the extent to which he was self-taught.

A more effective question, then, might be where he might have taught himself: what cultural milieux might he have learned in and from? In this section I step back from specifics to look at four such contexts which we have some reason to consider as possible candidates These are, in rough order, Irish anti-clericalism, British plebeian freethought, the intellectual culture of American hobos, and freethought in Asias3.

Of course in discussing this we are hamstrung by the very mystery surrounding Dhammaloka's early years which we are trying to resolve. Nevertheless, all observers who paid attention - hostile and otherwise - seem to have accepted his claim to be Irish-born (and indeed most played up his accent), while Harry Franck and two hobo companions all accepted his claim to be familiar with jumping trains and to have worked on riverboats in the US. British freethought has been included here because of its indirect significance in relation to Ireland, via working-class migration, and because of the body of research on plebeian freethought in the UK.

This fuzzy situation reminds us of the methodological difficulties of tracing the ideas that circulated among migrant workers. We should also recall the legal threats faced by proponents of free thought. To put these latter in context, the Blasphemy Act remained in force in the UK until 1921, when it was used to imprison freethinking pamphleteer J ohn Gott (it remained on the statute books for several decades subsequently). The publisher of Blue-grass blade was twice imprisoned for blasphemy in the US, the publisher of the Truth Seeker once, while as we have seen Dhammaloka also faced legal action. In this context, it is not at all surprising that records of working-class atheism in our period tend not to be overly high-profile; rather, it is surprising that so much is known.

Can we find any sense of a home for Dhammaloka's free thought?

\section{Ireland}

Royle (1974: 70) has this to say on freethought and Ireland:

On the continent of Europe, not to be a Catholic was to be a freethinker, but in Ireland, not to be a Catholic was to be a Protestant, often of the fiercest, most aggressive and most unreasoning kind. There was no room for freethought in Ireland. As the Freethinker commented in 1882, "Father Fennelly is proud that no 'infidel societies' have been established in Ireland. Quite so. They go in for 'assassination societies' over there. Murder isn't half as bad as infidelity. Better beat out your neighbour's brains than believe that J onah was not swallowed by a whale."

83 I am conscious in this section of the far larger literature on free thought in general; other than Ireland and Asia, however, I am attempting to trace in particular its plebeian strands and set them in social context, rather than the wider literature on middle-class free thought and its intellectual content. 
At the 1861 census on Irish education and religion, only twenty-one freethinkers (including one woman), twenty Secularists (three women) and nineteen Deists (three women) stated their positions to be such. Rarely does the historian get his perspectives set out in so clear a way. Organised freethought barely existed. Boyne managed a freethought society in 1875 and 1876; Cork had a branch of the N.S.S.[National Secular Society] in 1883. Otherwise, only Dublin and Belfast had anything to offer, which was very little. Secular societies appeared in both Dublin and Belfast in 1875, though neither lasted long. In March 1886 the National Reformer admitted that there was no organised freethought in Ireland, but in November of that year a branch was founded in Belfast, which lasted until the mid-1890s, and to which G.W. Foote paid a presidential visit in 1891. This society arose in reaction to the Belfast riots of the summer of 1886. It represented a small, untypical group of self-proclaimed "sane" men in a sea of religious folly ${ }^{84}$.

This much is fairly straightforward, but misses something important about the Irish context and its implications. In the second half of the nineteenth century - following Daniel O'Connell's earlier mass movement for Catholic emancipation - agitation for Home Rule was at its height; the Land War and subsequent Land Acts saw the effective dissolution of the (largely Protestant) aristocracy in favour of the (largely Catholic) tenantry; and the Anglican Church of Ireland was disestablished, at the same time as lengthy discussions handed control of the education of Catholic children to the Catholic church. The groundwork was being laid for the successful independence movement of the period 1916 - 1924 - and for the unionist, largely Protestant, reaction which led to the formation of the Northern Irish statelet.

In this situation, religious sectarianism was bound up with ethnic and political identities as well as with tribal affiliations and the provision of social services such as health and education (and sectarian riots were not unknown, either in Belfast and Derry or "mainland" cities such as Glasgow and Liverpool). Thus the kind of thoughtful, politically conscious working-class men who made up the backbone of British plebeian secularism in this period would not, in Ireland, allow their scepticism as to the tenets of religion or their hostility to the actual behaviour of the clergy express itself in active disaffiliation from "their" church - a pattern which remains true for working-class women activists in Ireland a hundred years later ${ }^{85}$.

As we shall see below, in London this issue could split Irish Fenians from English republicans, and needed constant attention. In Ireland, what stood in for open atheism was rather anti-clericalism. This finds neat expression in the works of Ireland's leading Marxist thinker, J ames Connolly - a founding figure to virtually all subsequent strands of socialist politics in Ireland, from the Labour Party through orthodox Communism to the far-left paramilitaries of the 1970s. In his Labour, nationality and religion Connolly - critiquing a J esuit attack on socialism - argues carefully

\footnotetext{
84 Edward Royle, Victorian Infidels: the Origins of the British Secularist Movement 1791 - 1866 (Manchester: MUP, 1974, 70). Elsewhere Royle notes the activities of the ex-clergyman and deist Robert Taylor who issued tracts and formed a society in Dublin in the 1820s before a student mob forced him to return to London and the existence of an Owenite class in Dublin between 1842 and 1844 (Royle, Victorian infidels, 37, 297). An obvious conclusion is that while Ireland was stony soil in which freethinking seeds were unlikely to flourish, this does not mean that no such seeds were sown there.
}

${ }^{85}$ Carol Coulter, The Hidden Tradition: Feminism, Women and Nationalism in Ireland (Cork: Cork UP, 1993). 
He serves religion best who insists upon the clergy of the Catholic Church taking their proper position as servants of the laity, and abandoning their attempt to dominate the public, as they have long dominated the private life of their fellow-Catholics.

\section{This is followed by}

a brief statement of some of the many instances in which the catholic laity have been compelled to take political action contrary to the express commands of the Pope and the Catholic hierarchy, and in which subsequent events or the more enlightened conscience of subsequent ages have fully justified the action of the laity and condemned the action of the clergy.

This is basically a list - drawn up from a nationalist point of view - of church association with the power of the British state: from association with Henry II's invasion of Ireland and opposition to the American War of Independence through to opposition to the rebellion of 1798, to rent strikes during the Famine, to Home Rule and the Land League ${ }^{86}$.

Connolly's overall political position can be summarised as the need to locate working-class socialism firmly within the (Catholic) national independence movement and as a radicalisation of that movement. Thus he is concerned to legitimate the position whereby one can be a radical, both in nationalist and class terms, and a "good Catholic" while hostile to the behaviour of the clergy and hierarchy and resistant to directives from above.

This position goes back well before Connolly as a hegemonic one on the (Catholic) Irish left. In the family politics of the time (as in twentieth-century Italy) such a position was workable in part because it legitimated plebeian radical men in their hostility to organised religion without forcing women and children - far more dependent on the respectability, rituals and social benefits attendant on church membership - into leaving the church. Thus, then as now, one could be a good republican, a good socialist and a good Catholic without seeing any contradiction between these positions.

Within what an outsider might regard as a piece of fancy footwork, there was of course scope for dissemination of more rationalist ideas. In particular, Thomas Paine - given nationalist and democratic legitimation by his association with the American Revolution was an obvious point of reference for Catholic-born anti-clericals. His Rights of Man had circulated widely between 1791 and the 1798 rebellion ${ }^{87}$ (Barnard 1999: 62), while in 1825 the Presbyterian moderator commented of the underground "hedge schools" that

the works of Tom Paine ... were put into the hands of the people. Paine's Rights of man, a political work, and Age of reason, a 'deistical' one, were 'industriously circulated'... 'not a few of the schoolmasters were men of bad principles, who preferred any book to the Bible' 88 .

86 J ames Connolly, Labour, Rationality and Religion (Dublin: New Island / Irish Socialist Library, 1972, orig. 1910, 5, 6 - 11).

87 Toby Barnard, "Reading in Eighteenth-Century Ireland: Public and Private Pleasures", in Bernadette Cunningham and Máire Kennedy (eds.), The Experience of Reading: Irish Historical Perspectives (Dublin: Rare Books Group of the Library Association of Ireland / Economic and Social History Society of Ireland, 1999, 60 - 77).

${ }^{88}$ Cited in Antonia MacManus, The Irish Hedge School and its Books, 1695 - 1831 (Dublin: Four Courts, $2002,36)$. 
Within this general framework of Catholic anti-clericalism, then, ideas which verged on free thought could be circulated, and no doubt learned from, by those who were not prepared to express them openly.

If Dhammaloka was (as seems most probable) Laurence Carroll, from a plebeian household on the outskirts of Dublin, educated up until some point in his teens and a young emigrant, it is highly unlikely that he was ever a member or even aware of the fleeting freethought or secular association in Ireland, except perhaps through denunciations from the pulpit. However, a general spirit of anti-clericalism, and perhaps a teenage familiarity with Paine in particular, is entirely plausible as background; and it is fair to say that a good proportion of Dhammaloka's attacks on Christianity - particularly those which he wrote himself rather than republishing - are attacks on Christian clergy in particular, tinged with a class hostility readily understandable to anyone who has seen the nineteenth-century streets of Irish towns, with their small rows of terraced houses overshadowed by the building boom of Church buildings. In Burma, this class-based anticlericalism could readily become an anti-colonial hostility to missionaries, particularly when expressed by a bhikkhu governed by an oath of poverty.

\section{Mainland Britain ${ }^{89}$}

In mainland Britain, by contrast, open free thought was widespread in comparable plebeian and radical - milieux. The Ireland of Dhammaloka's birth was in some ways very much part of the UK, not least in terms of publications and organisations, but also in terms of working-class migration in both directions. As we have seen, his polemical activity in later life drew on British as well as American sources. Those British sources may have been mediated through the American freethought movement - both being in close contact with each other - or from earlier contact in Ireland or Britain. Here it is useful to rehearse some of what is known about specifically plebeian freethought in Britain.

As readers of Christopher Hill and EP Thompson are aware, religious radicalism in the seventeenth century and anti-clerical rationalism in the eighteenth century were part of the political inheritance of plebeian British thought, although, as Thompson's later work on Blake makes clear, there was a growing divergence in the course of the nineteenth century between an increasingly complacent, Enlightenment rationalism that formed part of middle-class radicalism and the far less polite perspectives - radical Christian or socialist - of working-class thinkers ${ }^{90}$.

Urban Britain in particular was already far more secular than either Ireland or America (the "Victorian crisis of faith" impinging far more on the Anglican middle class than on city workers); and on the plebeian side of things the attraction of free thought by this period was far less an immediate urgency born of childhood socialisation or an all-pervasive

\footnotetext{
89 I am grateful to Keith Flett and BobJ ones for references and suggestions in this area.

90 Christopher Hill, The World turned Upside Down: Radical Ideas during the English Revolution (Harmondsworth: Penguin, 1975); EP Thompson, The making of the English Working Class (London: Gollancz, 1963); Witness against the Beast: William Blake and the Moral Law (Cambridge: CUP, 1993).
} 
presence in the community than, perhaps, its usefulness as a topic for debate and polemic, and a vehicle for class antagonisms.

\section{Free thought, anti-imperialism and the Irish}

The physical location for such discussions is explored in Shipley's seminal discussion of mid-Victorian working-class club life in London. This was a world of the self-taught, of earnest reading, and of intense debate about topics at the sharp edge of working-class politics. In 1872, for example, a one-year anniversary meeting was held with 16 leading survivors of the Paris commune, as well as Karl Marx and another 8 English speakers: participants in such meetings were not afraid of public hostility or state intervention, and often clashed with police attempting to break up demonstrations.

This radicalism was frequently expressed in opposition to their own state's policy in Ireland: "Home Rule for Ireland" was a routine subject for lectures, while the more advanced clubs, such as the Stratford Dialectical and Radical, opposed coercion after the Phoenix Park murders of the Chief Secretary and Permanent Undersecretary for Ireland in 1882. In similar vein were the politics of "The Star" Radical Club of Herne Hill, whose 1888 programme began as follows:

(1) Home Rule for Ireland; (2) manhood suffrage; (3) women's suffrage; (4) abolition of present House of Lords; (5) disestablishment of the Church...91

This connection was no coincidence: London, like Manchester, Liverpool or Glasgow, was in significant part an Irish city, and working-class radicalism had drawn on Irish migrants since at least the role of Feargus O'Connor and Bronterre O'Brien in the Chartism of the 1830s and 1940s. It is unsurprising, then, that delegates to the 1880 Land Law Reform Convention included one from Mayo (where the boycotts and "outrages" of the Land War were in full swing), while labour agitator Patrick Hennessy, lecturer in the same decade to the Social and Political Educational League, argued "the propriety of occasionally shooting an Irish landlord" 92 .

Support for anti-imperial struggles was widespread in plebeian London at this period: in Clerkenwell, mass demonstrations were held in the 1860s against the repression of J amaican protest and in support of Irish nationalism, following the latter of which Gladstone was forced to receive a "deputation of roughs headed by one Finlen, the most notorious of the pro-Fenian orators of Clerkenwell Green"; in 1871, however, contention erupted between the (Catholic) Fenians of the area and English sympathisers with the Commune93. This dispute was patched up by 1872, when Bradlaugh, founder of the National Secular Society, was the main speaker at a meeting organised by the radical

\footnotetext{
${ }^{91}$ Stan Shipley, Club Life and Socialism in Mid-Victorian London (Oxford: History Workshop, 1972, 23, 41); J ohn Taylor, From Self-help to Glamour: the Working Man's Club 1860 - 1972 (Oxford: History Workshop,1972, 44).

${ }^{22}$ Shipley, Club Life, 68, 70.

93 Similar clashes had occurred in 1862, for and against the French occupation of Rome (Royle, Victorian Infidels, 255).
} 
London Patriotic Club in support of speakers prosecuted after a previous meeting demanding amnesty for Fenian prisoners ${ }^{94}$.

From this point on, an alliance between the (secularist, atheist) London working class republicans and the (nationalist, Catholic) Irish labourers of Clerkenwell was central to the politics of the Club up to the late 1880s. Thus it supported Home Rule and the Land League and systematically opposed coercion in Ireland; it extended this to support for Balkan revolts against Turkey in the 1870s, to the British invasions of Egypt and the Sudan in the 1880s, and to Indian nationalism in the $1890 \mathrm{~s}^{95}$.

An alliance between republican radicalism of a free-thinking kind, Irish nationalism and support for anti-colonial struggles more globally, then, was for a time a major political achievement of radical London. In this world, we find regular club lecturers like Richard Butler, a trade union activist from the 1860s to the 1880s, whose

special subject was Ireland, and Hyndman, the newcomer, had probably not heard his lecture on Henry Grattan, or the one called "Daniel O'Connell, Isaac Butt, and CS Parnell: a Comparison" 96.

Butler debated for Christianity versus Atheism at the Manhood Suffrage League in 1876 against determined opposition. By contrast, the equally Irish-sounding Miles or Myles McSweeney - an old Chartist and a key member of the London Secular Society -

Could reduce "Christ to a Solar Myth" in a "quaint style" which club members knew and loved. When he died in 1881 subscriptions for his funeral were sent in from all over London.

McSweeney was a lapsed Catholic who described himself as an enemy of the "Romish" priesthood, equally happy to speak on the continuing relevance of the Chartist uprising or on anti-Christian themes ${ }^{97}$. If McSweeney's secular radicalism was made possible by stepping away from Irish nationalism, while Butler's class-conscious nationalism nevertheless required him to defend Christianity, we can at least see both of them working out some of the same problems that Connolly, Dhammaloka - and many other plebeian Irish radicals - were struggling with.

Freethought and working-class clubs

J ust as such people came to different conclusions and emphases, so working-class clubs in the London of the 1870s and 1880s had different characters:

Some were proclaimedly Radical, some Freethought and Secularist, some expressly educational, some more inclined to be free and easy [i.e. focused on entertainment]: but they often combined all these features and more besides.

94 Andrew Rothstein, A House on Clerkenwell Green (London: Marx Memorial Library, $2^{\text {nd }}$ edition 1983, 35, $40,45,49)$.

95 Rothstein, House on Clerkenwell Green, 49 - 51.

96 Shipley, Club Life, 53 - 4.

${ }^{97}$ Shipley, Club Life, 37, 25. 
Anti-clericalism was a long-standing feature of such clubs: already in 1852 the London City Mission Magazine was discussing the "J ohn-street Infidel Hall", which it saw as "the centre of Infidel organization for the kingdom at large":

In politics they are Chartists of the Democratic Socialist order, and professedly they meet to discuss political questions; but Atheism, Deism, or scepticism in some of its forms is usually mixed up with every political debate. A Christian's blood well nigh runs cold with horror at the blasphemies which are sometimes uttered here... [a lecture on Mazzini] was only an argument to degrade the Lord J esus, by attempting to prove that such men as Mazzini, Carlyle, Tom Paine, and Robert Owen, were quite equal to Him...

\section{In the 1870s another observer discovered}

In those days science and religion - the clergy and the scientific teachers - were deadly foes, and [the lecture] was full of sly drives at the clergy, chiefly those of the Church of England, which were highly appreciated by the audience.

By the 1880s, "the London clubs became a by-word (among Christians) for their atheism", electing Bradlaugh as vice-president of the national Club and Institute Union ${ }^{98}$. If workingclass clubs were largely secularist, so too the London secularist movement was determinedly working-class; one observer noted that the Hall of Science (to its enemies the "School of Blasphemy, Political Vandalism and Social Retrogression") was full of tradesmen, artisans, sailors, labourers and navvies in working clothes; for many participants at the Hackney Secular Association "the close connexion of cleanliness with godliness had been so practically recognised, and they abjured the former with the latter". Nor were these small groups: their membership in the 1870s was roughly 1000 and 800 respectively ${ }^{99}$.

By this point, the rhetoric of secular atheism was increasingly stale, and there was a turn in many clubs from secularism to socialism from the 1880s on. If by the turn of the century secularism was no longer at the cutting edge of working-class thought, nevertheless a general hostility to organised religion had become an acquis communautaire for workingclass radicals, as the United Radical Club's banner illustrated:

The reverse displays a figure of Liberty trampling upon the prostrate form of Despotism, with his shattered shackles and his minions, Priestcraft and Privilege...100

Political radicalism at home, opposition to imperialism abroad, self-confident workingclass identities and freethought were all common features of this milieu.

Ireland and England

Dhammaloka's use of secularist rhetoric in a cultural nationalist context is nonetheless an innovative one: if Irish radicals at home were content to assert the compatibility of their multiple allegiances, and those in London had to work hard to prevent the alliance between working-class radicalism and Irish nationalism falling apart over the question of

\footnotetext{
98 Taylor, Self-Help to Glamour, 47.

99 Shipley, Club Life, 37 - 8.

100 Cited in Taylor, Self-help to Glamour, 50.
} 
freethought versus Catholic loyalty, his ability to be determinedly Irish and anti-colonial, but at the same time step completely outside a Christian identity, no doubt depended on being outside the immediate context, where Catholic nationalism was the central issue in Irish politics both in Ireland and in Britain. Of course, the Buddhist context also provided the possibility of deploying freethought rhetoric in a way which was supportive of a different kind of religious identification; and perhaps in this respect a more plausible, if less sophisticated, one than Connolly's attempts to square the circle.

McSweeney, Butler, Hennessy and the unnamed Mayo delegate, Annie Besant and J ames Connolly make it clear that Britain and Ireland were not two hermetically sealed worlds, particularly not for migrant workers and radical activists. Whether Dhammaloka had any direct connection with this London plebeian radicalism is unclear, and perhaps beyond discovery in this world of insurrectionists, exiles and migrants. Fancifully perhaps, we can draw parallels from the young Antonio Gramsci at the turn of the century - growing up in an impoverished household in peripheral Sardinia and turned away from Sardinian nationalism to socialism through the influence of his older brother, a migrant worker in industrial Turin - or note the ways in which American radicalism drew on radical exiles and migrants from Europe (including the Soho O'Brienites who converged on Kansas with Remsburg).

We are on less speculative terrain if we say that in London we can get an unusually clear glimpse of a world which is recognisably close to Dhammaloka's in terms of its ideas, experiences and politics: a world mainly of self-confident and self-educated working men, conscious of class antagonisms and nationalist opposition to the empires of the day, enriched by the experiences of labour migrants and exiles or survivors from revolutions and uprisings, hostile to established religion and fond of a good polemic. We can also see how freethought might be another layer of concerns that participants sought to relate to nationalism and social radicalism, rather than an essentially separate tradition.

\section{Spiritualism and plebeian radicalism}

In similar vein, we can note Barrow's important work on the plebeian relationship to spiritualism in this period. Although too complex to summarise easily, this distinguishes between an elite and a plebeian form of spiritualism- the former tending more towards becoming an alternative religion, the latter tending more towards self-understanding as scientific and anti-religious - and notes the extensive organisational form of the latter throughout England ${ }^{101}$.

This relationship was also present in Ireland, for example in the young Patrick Breslin, spiritualist and later sympathiser with Buddhism who was simultaneously involved in the foundation of the Irish communist movement and indeed sent to the International Lenin School in Moscow ${ }^{102}$. Breslin was involved in a controversy while in Moscow over his

\footnotetext{
${ }^{101}$ Logie Barrow, Independent Spirits: Spiritualism and English Plebeians 1850 - 1910 (London: Routledge and Kegan Paul / History Workshop, 1986).

102 Barry McLoughlin, Left to the Wolves: Irish Victims of Stalinist Terror (Dublin: Irish Academic Press, 2007).
} 
defence of spiritualist positions as compatible with historical materialism (echoing Connolly's defence of socialist Catholics). Later, when sent to the gulag for other reasons, the prison psychiatrists simply noted that his views on spiritualism were compatible with the latest positions of modern science. This reminds us that what we now take to be a religious or magical position was by no means self-evidently so in the late nineteenth century; Barrow discusses the reasons for this, noting that at the time spiritualism seemed to offer a scientific and miracle-free relationship to the afterlife, devoid not only of Christian dogma but (crucially) of the need for priestly intermediaries.

Spiritualists, freethinkers and Christians, in fact, fought a three-cornered battle, with some spiritualists identifying themselves closely with atheism while others were more "religious" in temper. Spiritualist and freethought periodicals were both in dialogue and in violent opposition to each other in various times and places. Belief in spirits and the possibility of contacting them could coexist with a radical critique of Christianity as mystical and irrational (as with Dhammaloka's Arakan declaration, which moves from denouncing Christianity as anti-scientific to invoking "the star-like Buddhas"), and with a plebeian selfconfidence worthy of note.

This matrix is particularly important, of course, given that Theosophy developed out of spiritualism. In Britain in particular, Buddhist affiliations came out of Theosophy (in some cases indirectly: Ananda Metteyya had started out in the post-Theosophist Golden Dawn). This was also the world in which the Irish-identified socialist Annie Besant was a close associate of Bradlaugh and a highly popular secularist lecturer in her own right before becoming a Theosophist and centrally involved with the Indian independence movement ${ }^{103}$; and it is the world in which the moderate Irish nationalist J ohn Bowles Daly, later co-organiser with Col. Olcott of Buddhist Theosophical Society schools in Ceylon in opposition to mission schools, abandoned his missionary career in the East End in despair at the social reality of Christianity in London ${ }^{104}$.

To some degree the survival of the British, and particularly the London, material, and the quality of research on it, is an accident of history: because this is the world of Marx and other political exiles from Europe, a world of survivors from Chartism, and the world from which the new trade unions and left parties were to grow, it is both particularly welldocumented and well-researched. This material provides us with a window onto a world where we can see that a combination of aggressive freethought, a self-confident and autodidact working-class identity, and what we would now think of as "religious" positions was by no means unusual in the period in question.

This mixture parallels the experience of other Irish Buddhist sympathisers, whose contexts are much shadowier: Lafcadio Hearn moved from freethought through agnosticism towards Buddhist sympathies; Bowles Daly moved from spiritualism to Theosophy and

\footnotetext{
103 Shipley, Club Life, 35, 39. In the police attack on the mass demonstration of 1877, known as "Bloody Sunday", half of the East Finsbury club's banner was recaptured from the police by "one of the member's wives and Mrs. Besant" (cited in Taylor, Self-Help to Glamour, 52).

104 Laurence Cox and Maria Griffin, "The Wild Irish Girl and the 'Dalai Lama of Little Thibet': the long Encounter between Ireland and Asian Buddhism". Forthcoming in Olivia Cosgrove, Laurence Cox, Carmen Kuhling and Peter Mulholland (eds.), New Religion in Ireland (Cambridge: Cambridge Scholars Publishing).
} 
Buddhism and back towards mysticism; Patrick Breslin combined spiritualism, Buddhist sympathies and communism; and Dhammaloka consistently attempted to combine free thought and Buddhism. If these forces are best-known for radical London, they were not absent in comparable cultures elsewhere.

\section{The USA}

Another such milieu was that of the American working-class left, particularly its migrant sections. Avrich's history of the early twentieth-century freethinking Modern School movement in the States shows us elements of a similar world, strongly influenced by European immigrants such as Dhammaloka ${ }^{105}$.

Migrant labour - "hoboing" - was no obstacle to working-class intellectual activity, as Harry Franck's experience shows; and American research has paid close attention to this. Migrant workers in the US were voracious readers:
Investigators identified bad conditions with degradation because they ignored or underestimated the importance of the working-class cultural milieu. In part, they failed to see the importance of family networks that laborers relied on in tough times. But they also underrated the power of a broadly populist intellectual subculture as a basis for alternative interpretations of working-class existence. Moreover, investigators rarely took hobo intellectual life seriously because they could not agree with its radical tone. J osiah Flynt noted the keen interest of tramps in all kinds of reading material, especially dime novels and books on political and economic topics. They would use the latter at their "hang out conferences", where they competed to offer the most compelling social analysis. According to Flynt, they liked "any book ... which 'shows up' what the tramps consider the unreasonable inequalities in our social conditions." Flynt saw these debates as self-serving escapism on the part of men who wanted to blame society for their condition. However, laborers' memories of their coming to intellectual maturity through the IWW and other radical movements suggests a more authentic engagement with ideas. Thomas Bogard linked his radicalism to his early reading of Terence Powderly's Thirty years of labor and the popular socialist weekly Appeal to reason, along with stories about the Knights of Labor told by his first employer. Although Vincent Dunne left school at fourteen to work as a lumberjack and harvest hand, later he was befriended and tutored by a fellow radical worker with a large private library. Laborers of Finnish background recalled the extensive Finnish socialist and religious press. And laborers of varied backgrounds often read - and wrote letters to - the International Socialist Review and the IWW's newspapers Solidarity and Industrial Worker.

Given their frequent unemployment, laborers had plenty of time on their hands, and many of them used that time to read and talk. The Chicago hobo bookstore owner Daniel Horsely guessed that at least half of the migrant workers were avid readers. Generally, they favored "liberal, free thought and radical" magazines, scientific works, and realistic fiction, in addition to newspapers and whatever they could acquire with their limited means. Magazines such as the International Socialist Review were intended to meet these needs and interests as well as promote socialism ${ }^{106}$.

\footnotetext{
105 Ben Reitman, who we have encountered sharing column space with Dhammaloka in The truth seeker, was involved in the Modern School movement; a college-educated newcomer found him "a vulgar and unstable character", rather like missionaries' comments on Dhammaloka (Paul Avrich, The Modern School Movement: Anarchism and Education in the United States, Oakland, AK, 2006, 126).
}

106 Frank Higbie, Indispensable Outcasts: Hobo Workers and Community in the American Midwest, 1880 1930 (Urbana: U. Illinois, 2003, 191-2). 
Such men went on to become key organisers for the Industrial Workers of the World and, later, the Communist Party; organisational skill was not incompatible with migrant labour. Free thought in particular was well represented in this culture, in a form which is immediately recognisable as related to Dhammaloka's:

With deep roots in continental Europe, anticlerical ideology based on Enlightenment rationalism was best represented by Tom Paine's famous tract The Age of Reason (London, 1794), which enjoyed great popularity among radical workers in the United States in the late nineteenth and into the twentieth century. Free thought blossomed alongside the labor and socialist movements in the United States among both immigrant and native-born workers. The magazine Free Thought (New York) remained the movement's most important English-language organ in this era. Robert Ingersoll (1833 - 99), Illinois writer, lawyer, orator and politician, was perhaps the best-known American advocate of rationalism and atheism... ${ }^{107}$

Paine and Ingersoll both feature in Sophia Egoroff's list of "great men". A related set of positions appears in the subtitle of the Truth Seeker: it was

Devoted to science, morals, freethought, free discussion, liberalism, sexual equality, labor reform, progression, free education and whatever tends to elevate the human race. Opposed to priestcraft, ecclesiasticism, dogmas, creeds, false theology, superstition, bigotry, ignorance, monopolies, aristocracies, privileged classes, tyranny, oppression and everything that degrades or burdens mankind mentally or physically.

A populist combination of free thought and social and political radicalism, then, was widely available to European migrant workers in the US; when the Irish-born Lafcadio Hearn emigrated to the States, he encountered Fourierist and anarchist ideas in his first job as a printer and began writing articles for the freethought Investigator on religion and Eastern philosophy 108 - the journalism taking him to New Orleans and the interest eventually to J apan. It is entirely possible that Dhammaloka encountered freethought in this context as a migrant worker; the claim that he read Olcott in the States is by no means impossible - it may even have been part of what brought him to Asia.

\section{Freethought in Asia}

This working-class reading culture travelled, with American and European migrant workers, to Asia. Franck noted of the Sailors' Home in Chittagong (where Dhammaloka had good relations with the local Buddhist community)

Had we rented by cable some private estate we could not have been more comfortably domiciled than in the Sailors' Home of Chittagong. The city itself was a garden-spot, the Home a picturesque white bungalow, set in the edge of the forest on the river bank. The broad lawn before it was several acres in extent, the graveled walk led through patches of brilliant flowers. Within, the building was furnished almost extravagantly. The library numbered fully a thousand volumes - by no means confined to the output of mission publishing houses - in one corner were ranged the latest English and American magazines, their leaves still uncut ${ }^{109}$.

${ }^{107}$ Hutchins Hapgood (ed. J ames R Barrett), The Spirit of Labor (Urbana: U. Illinois, 2004, orig. 1907, 413). 108 Paul Murray, A Fantastic J ourney: the Life and Literature of Lafcadio Hearn (Folkestone: J apan Library / Curzon, 1993, 26).

109 Franck, Vagabond J ourney, 375. 
While this particular home was presumably - as Franck implies - funded by wealthy patrons, it makes it clear that just like American hobos, European sailors in Asia were not "bare life" devoid of intellectual stimulus; even their benefactors expected them to read voraciously 110 .

By Franck's day, radicals arriving in Asia could also find overt freethought - and indeed a combination of freethought and Buddhism which echoes, and at times overlaps with, Dhammaloka. The long-lived J ames Peebles in Ceylon published Dhammaloka's Buddhism and Christianity side by side with A historical criticism of the New Testament, suggesting a similar combination of Buddhism and freethought to Dhammaloka's own ${ }^{111}$, while as seen the Colombo BTS was publishing texts which "were mostly reruns of Bradlaugh"112.

Meanwhile, a contemporary Who's who noted of Remsburg that "Portions of his writings have been translated into French, Italian, German, Dutch, Swedish, Norwegian, Bohemian, Bengali, Singalese and J apanese." 113 Someone in Ceylon (perhaps Peebles), but also someone in J apan, was busily importing and translating freethought texts in this period presumably as a weapon against Christian missionaries, since it is hard to imagine any other use for Sinhala or J apanese critiques of Christianity. Other than the Peebles Dhammaloka link, it is not yet clear whether the Colombo BTS, the Sinhala Remsburg translation and the J apanese one were part of a network or independent developments.

If Western freethought was a useful tool in opposing missionaries, Southeast Asian Buddhists in particular had a long-standing hostility to theism as construed in the Pali canon. As is well known, they often welcomed, or colluded with, western presentations of Buddhism as "morality without God", "religion without blind faith", "scientific religion" and so on ${ }^{114}$.

Thus in Burma, where there was a group questioning religion as early as the $1880 \mathrm{~s}^{115}$, it did not seem incongruous for a note in Buddhism, the house journal of Ananda Metteyya's International Buddhist Society, to state the Society's intention to attend what it described as the first International Freethought Congress ${ }^{116}$. In similar vein, a Dhammaloka piece in Teachings of J esus...notes

\footnotetext{
110 Alston Kennerley, "Writing the History of Merchant Seafarer Education, Training and Welfare: Retrospect and Prospect", The Northern Mariner / Le Marin du Nord XII no. 2 (April 2002, 1 - 21) notes that sailors' homes were provided by secular organisations, whether state, trade unions or voluntary societies.

${ }^{111}$ Peebles, What is Religion? 32.

112 Young and Somaratna, Vain Debates, 210.

${ }^{113}$ Ingalls, History of Atchison County, 505.

114 This was assumed by Clark: "A personal God is an abhorrence to a strict Buddhist." ("Buddhism on the Warpath", 249).

115 Alicia Turner, pers. comm.

116 Buddhism vol. 1, 1903, 677. The first such Congress had in fact been held around 1860; the one in question may have been the Geneva meeting of 1903 or the Rome one of 1904. In 1905 Ananda Metteyya wrote to the Congress stating the identity of Buddhist and agnostic positions (Stephen Batchelor, "The other

Enlightenment Project", online at http:/ / www.stephenbatchelor.org/ other2.html\#3, accessed 18.9.10).
} 
Surely if the Rev. W. F. Armstrong and his revivalist coadjutors are the experts they claim to be in converting Buddhists and Free-Thinkers to the faith, the great educationists of their own country present the finest material upon which they could exercise their powers.

- implying an overlap or identity between Buddhists and freethinkers going beyond his own perspective ${ }^{117}$. A 1907 Burma Echo included the following notice, possibly in connection with the foundation of Dhammaloka's Burma Freethought Association:

It will, perhaps, come as a surprise to many people to learn that, in Rangoon there are considerably more than 300 European and Eurasian Free-thinkers, many of whom subscribe to English and American J ournals of Free-thought. These people are all avowed Free-thinkers and never enter a Christian church. Of course this is not all the Eurasians and Europeans in Rangoon that never enter a Christian Church. There are many others that never attend Church for reasons entirely apart from anything approaching Agnosticism or Free-thought 118 .

If more scholarly interpreters, and those more steeped in Buddhist texts, were keen to argue the scientific and rational nature of Buddhism on the basis of suttas and commentaries, Dhammaloka here implies what is visible from his own writings, that it was possible to be a Buddhist, assume that this was compatible with rationalism, and defend the latter position - or attack Christianity - on the basis of "English and American J ournals of Free-thought", from which assertions as to the compatibility of Buddhism and free thought could be made.

The scholarly position, perhaps, highlighted the more respectable emphasis on science and rationality; while the more plebeian one was happier to use the polemical term "free thought", and rely on western-made ammunition for a struggle within Asia against Christian missionaries ${ }^{119}$.

\section{The search continues}

If we cannot answer the question of whether Dhammaloka became a freethinker in Europe, America or Asia, this is because free thought was equally available, in plebeian and radical contexts, in all three continents. On the face of it, it might seem likely that Dhammaloka had become a freethinker as migrant worker in the west and subsequently, in Asia, found Buddhism a suitable means of expression. However, on his own account he had spent relatively little time (2 years) in the US, followed by a long period in Asia (he claims to have arrived in Burma at least before the third Anglo-Burmese war of 1885).

If so, perhaps his first commitment was to Buddhism and freethought, like temperance, was a suitable weapon to be wielded against missionaries and, by extension, against a

\footnotetext{
117 Alicia Turner's article discusses the encounter between Dhammaloka and "two or three English gentlemen, who seemed to be freethinkers" in Bassein in 1901.

118 Burma Echo, "Free-thinkers in Rangoon", October 12 1907, 12. Alicia Turner (pers. comm.) notes that even if this figure is an exaggeration, there was certainly a substantial number of theosophists and others interested in western occultism by this point.

119 Cotes, "Ordination of Asoka", mentions a "Stoic" friend - clearly a civil servant whose career might suffer if identified publicly - who is definitely a skeptic and perhaps leaning towards atheism, familiar with Buddhism but not convinced.
} 
colonialism which was by this point inextricably linked with Christianity. While his encounter with Buddhism is occasionally mentioned by commentators - variously ascribing it to reading Olcott in the US or becoming converted in Burma - neither Dhammaloka nor observers seem to have taken his allegiance to freethought as being remarkable enough to require comment; and perhaps, indeed, for a thoughtful migrant worker of the period, it was not.

It may be the case that as the first decade of the twentieth century wore on Dhammaloka became more overtly "free thought" and less "Buddhist", perhaps in response to an increasingly genteel cohabitation between scholarly Buddhism and the colonial milieu, or perhaps as a result of devoting more energy to editing free thought texts than he had in the past; but both elements are present throughout the decade, and indeed in the last apparently reliable account we have of him. According to Purser, although notice of his death had appeared in Burma Dhammaloka was

very much alive in Siam as President of the Buddhist Free Thought Association: he does not love 'the missionary, fanatical fool or lazy knave armed with Bible and gin bottle, etc.' 120

As with the search for origins, so too the search for endings peters out. J ust as Dhammaloka's biography gives us only a sketchy and contradictory past and a disappearance, replete with spurious obituaries, so too the sources of his relationship to Buddhism and freethought remain rich with possibility - not least because, as this article has hopefully shown, these connections (Buddhism and freethought, freethought and spiritualism, plebeian radicalism and freethought) were widespread at the turn of the twentieth century. Later outcomes shape our perception to foreclose possibilities that intelligent participants at the time saw as wide open or even so obvious as to require no comment.

\section{Conclusion: the great unwashed and the many-headed hydra}

In attempting to track down Dhammaloka, I have suggested that a central difficulty lies in the assumption of training in specific and mutually exclusive organisational settings, allegiance to neatly bounded intellectual traditions transmitted in specific institutional locations, and tightly place-bound cultural milieux - shadows of one kind of university. Taylor, however, suggests a different way of thinking the university; writing of workingclass Britain in the 1870s and 1880s, he comments

The clubs of the day created an age of discovery, and the movement was a veritable Aladdin's cave, containing a profusion of intellectual treasures. In those areas where a high concentration of these "club colleges" existed - London, for example - the aggregate formed an unofficial Workers' University. The affiliated clubmen could move from club to club, lecture hall to lecture hall, sampling the wares of the itinerant lecturers, and exercising his own powers of debate ${ }^{121}$.

120 Purser, Modern Buddhism in Burma, 87.

121 Taylor, Self-help to Glamour, 93. 
We should extend this description beyond the specifics of London to say that such high concentrations could be found in multiple locations, and for migrant workers the Workers' University could be an international one. Similar ideas may have been encountered in multiple locations - plebeian anti-clericalism in Dublin, a working-man's club in London, a hobo bookshop in Chicago, a sailors' home in Chittagong, or copies of battered, selfpublished tracts passed from hand to hand - and put together in different combinations in different minds or tried out in debate and discussion.

To get a sense of the quality of some of the students in this university, we can compare Dhammaloka, who claimed to have been "sailor, tramp, shepherd, truckman, stevedore and tally clerk" before becoming a monk, to J ames Connolly, his near-contemporary, who worked as printer's devil, soldier, labourer and manure carter before he became a professional activist. Dhammaloka was (almost certainly) born in Ireland and a hobo in the US before his career in Burma, Singapore, India and Siam; Connolly grew up in Scotland, worked in Ireland and the USA, and had (probably) been a soldier in India (Nevin 2005).

Such people were capable of working out original answers to the problems they were faced with - in both cases, the relationship between religion and power - and putting those cases in ways that affected thousands of people in powerful movements that combined religiously-defined cultural nationalism with political and social radicalism.

Connolly and Dhammaloka's work is of course very different in many respects, but shares a preference for the pamphlet over the monograph, for the polemic over the exposition, and for a drawing-out of the implications of particular facts over the development of narrowlydefined chains of argument: in other words, for the intellectual practices of this sociable working-class culture as against those of the university or the church.

In this sense, the image of a "many-headed hydra", employed by Linebaugh and Rediker to discuss how radical ideas and practices spread around the $18^{\text {th }}$-century Atlantic between soldiers, sailors, slaves, and workers, may be more helpful, in its images of the flows of different practices, ideas and people: intermingled, and largely beneath the field of vision of state, employer or church until they emerged to directly challenge them ${ }^{122}$.

This may also give us a better sense of where to look for the sources of Dhammaloka's organising capacities: rather than seeking to identify him as a junior member of a particular committee (or as a lesser defendant in a political trial), we might rather see him as an occasional participant who did not get caught but learned from his experiences and from stories told by others - whether stories of the 1798 rebellion in Ireland, of the Chartists in Britain, of the international networks of freethinkers, anarchists and socialists, of trade union organising in the US, or indeed of the Maha Bodhi and Theosophical societies in Asia.

In other words, we may not need to set Turner's interpretation of Dhammaloka in terms of the Burmese Buddhist Revival, with its specific concern for moral reform, in opposition to that which I have advanced here, of Dhammaloka as speaking from a self-confident and international plebeian retort to established Christianity, or to set either against my

\footnotetext{
122 Peter Linebaugh and Marcus Rediker, The Many-headed Hydra: the Hidden History of the Revolutionary Atlantic (Boston: Beacon, 2001).
} 
exploration of Irish participation in the Asian Buddhist Revival in terms of anti-colonial solidarity and the translation of religiously-grounded cultural nationalism ${ }^{123}$. Rather, what made Dhammaloka effective was perhaps his ability to join up these various dots - or, as social movement theory has it - align these frames, in new and effective ways.

\section{The view from above}

This perspective - of Dhammaloka as Buddhist revivalist and plebeian freethinker and Irish supporter of Burmese nationalism - is incidentally borne out by his enemies. Hostile commentary, whether by missionaries or the English-language newspapers of the "colonial community" in Asia, accused him of pretty much exactly these things, as interrelated charges: Dhammaloka was bad news because his Buddhism was aimed at the Burmese rather than at Westerners, because he was hostile to Christianity, because he was no gentleman and because he was Irish.

Commentary routinely contrasted Dhammaloka with "good European Buddhists" like Ananda Metteyya. Metteyya, in what almost seems to be a stylised account, was presented as a gentleman scholar who understood Buddhism as philosophy rather than as politics; who sought rather to introduce it to educated people in the west than to use it as part of Burmese nationalist mobilisation; and who sought to see Buddhism recognised as a world religion rather than use it as a challenge to Christianity.

These criticisms of Dhammaloka were serious enough, in the hands of the powerful, to form the basis of his two known brushes with the law, both of which (as Alicia Turner's paper shows) raised the issue of sedition, paralleling missionary and newspaper concern that he was disturbing the simple faith of the Burmese and turning it into something it was not supposed to be: a source of tensions with Christian missionaries and - behind the missionaries - the empire, and the colonial elite ${ }^{124}$.

Sedition as a charge referred specifically to attacks (assumed when framing the legislation to come from native journalists) on imperial officials, white colonists and Christianity. He was in this sense (and we have it from the authoritative pen of the Irish-born J ustice Twomey) a trouble-maker, someone who (in WB Yeats' near-contemporary lines on Irish nationalist Maud Gonne)

Would hurl the little streets upon the great

Had they but courage equal to desire...

If Dhammaloka allied himself with the "natives" of the "little streets", rather than forming part of the automatic caste solidarity of "whites", he was also disreputable simply because

\footnotetext{
123 Turner, "Buddhism, Colonialism and the Boundaries of Religion"; Cox, "Plebeian freethought".

124 Thus, for example, he was capable of saying "he would go away from Burma, only after he had impressed on the minds of the Burmese the utter falsehood of the invaders' arguments ... in short, only after he had made the aggressors quit the province for ever, on finding their attempts here were futile". "Bassein", The Times of Burma, February 16 1901, 6. "Invaders" and "aggressors" could obviously have two very different meanings here, little more than a decade after the final "pacification" of Burma.
} 
he was Irish - an accusation which slides over into class prejudice: he was no gentleman. This comes out above all in discussion of language and education.

J ournalists and other western commentators present Dhammaloka as speaking with a strong "stage Irish" accent - despite the fact that as a working-class Dubliner his accent would have been far from this. By this period, unlike the $18^{\text {th }}$ century, regional accents in English were largely a marker of class status: radical nationalist and future President Eamonn de Valera had what we would describe as a "received pronunciation" accent, as no doubt did Irish-born members of the colonial elite such as Twomey or the civil servant Maurice Collis 125, so that to say he had a strong Irish accent was also to say that he was uneducated or lower-class, and this latter point is equally emphasised in hostile commentary.

The charge of being uneducated, illiterate, unpolished and so on recurs constantly although it did not stop him being capable of defeating missionaries in debate and delivering short, powerful speeches and pamphlets. Also combining ethnic and class prejudice is a recurrence of jokey stories; even a generally supportive newspaper article commented

When writing of an Irishman, one is always inclined to look for quips and cranks ${ }^{126}$.

These quips and cranks were not sought when the Irishman in question was a universityeducated magistrate such as Twomey (or indeed Morphy, the paper's editor), but referred specifically to the plebeian Irish, with their strong accents and outlandish, or gauche, behaviour.

From the side of the guardians of empire, orthodoxy and colonial privilege, then, Dhammaloka was Not One Of Us: an unrefined, uneducated member of the "great unwashed" who had so far forgot his racial duty of respectability as to wear native dress and bow down to idols, here he was uttering libels on the eternal verities of Christianity (and the behaviour of missionaries) and seeking to "stir up the natives". Our ignorance about the details of his past and intellectual affiliations is in part a product of this "view from above" which is most of what has survived - and which was more concerned to establish that he was "the wrong sort" than to go into details.

\section{The last word to Dhammaloka}

We can finish, however, with a partial corrective to this top-down view of Dhammaloka. In May 1905 hobo journalist Harry Franck, engaged on what was to become A vagabond journey around the world, encountered him three times, while Franck and his companions were travelling from Calcutta to Rangoon via Chittagong ${ }^{127}$.

\footnotetext{
125 Cox, "Plebeian Freethought".

126 Straits Times, August 261903.

127 Franck, Vagabond J ourney.
} 
Franck and his hobo companions satisfied themselves as to Dhammaloka's hobo credentials in discussion about jumping trains and working on river boats, and gathered various useful stories about Dhammaloka's life which seem - at a minimum - more plausible than the versions of himself he presented to courts, missionaries or hostile colonial editors. As part of their extended encounter, Franck and Dhammaloka had a discussion, between two hobos, about religion. Here then is Dhammaloka in conversation with his peers ${ }^{128}$ :

128 The dates of Franck's itinerary, and the "translation" of Dhammaloka's speech from the stage Irish into which Franck, five years later, rendered it, are Brian Bocking's.

50 
On the sagging gangplank of a tiny steamer, moored at the foot of the slippery bank, stood the Irish Buddhist, his yellow robe drawn up about his knees, scrubbing his legs in the muddy water.

"Good morning to you!" he called, waving a dripping hand. "Come on board and we'll have a chat. She don't leave till noon."

"The time'll pass fast," I suggested, "if you'll give us your yarn."

"Sure and I will," answered the Irishman, " if you'll promise to listen to a good straight talk on religion after."

What was it in my appearance that led every religious propagandist to look upon me as a possible convert? Even the missionary from Kansas had loaded me down with tracts.

The Irishman led the way to a cool spot on the deserted deck, sat down Turkish fashion, and, gazing out across the sluggish, brown Ganges, told us the story of an unusual life.

He was born in Dublin in the early fifties. As a young man he had emigrated to America, and, turning "hobo," had traveled through every state in the Union, working here and there. He was not long in convincing both Rice and me that he knew the secrets of the "blind baggage" and the ways of railroad " bulls." More than once he growled out the name of somejunction where we, too, had been ditched, and told of running the police gauntlet in cities that rank even to-day as "bad towns."

"Two years after landing in the States," he continued, " I hit California and took a job trucking on a blessed fruit-boat in the Sacramento river, the Acme - "

"What!" I gasped, "The Acme? I was truckman on her in 1902."

"Bless my eyes, were you now?" cried the Irishman. "Tis a blessed small world. Well, it was on the Acme that I picked up with a blessed old sea-dog of the name of Blodgett and we shipped out of Frisco for J apan. Blodgett, poor boy, died on the voyage, and after paying off I went on alone, fetching up at last in Rangoon. The English were not holding Burma then, and white men were as rare as Siamese twins. Bless you, but the natives were glad to see me, and I lived fine. But best of all, I found the true religion, as you would call it, or philosophy as it should be called. When I was sure it was right I took orders among them, being the first blessed white man to turn Buddhist priest."

"Good graft," grinned Rice.

"The remark shows your ignorance," retorted the son of Erin.

"Listen. Up to the day of my confirmation I was drawing a hundred rupees a month. I quit my job. I gave every blessed thing I owned to a friend of mine, even to my socks. At the temple, an old priest made me a present of a strip of yellow cloth, but they tore it into three pieces to make it worthless, and then sewed the pieces together again for a robe, and I've worn it, or one like it, ever since. If I'd put on European clothes again, even for one day, I'd be expelled. I cut off my hair and as fine a moustache as ever you saw. If I'd let them grow again I'd be expelled. If I'd put on a hat or shoes I'd be expelled. So would I if I owned a 
farthing of money, if I should kill so much as a flea, if I'd drink a glass of arrack, if I touched the oldest hag in the market place with so much as my finger."

"Fine graft, say you and your likes. Listen to more. When I took the robe, and that's twenty years and gone, I became a novice in the famous Tavoy moonastery. Every blessed morning of my life for five year, I went out with the other novices, hugging a big rice bowl against my belly. We stopped at every blessed house. If we'd asked for anything we'd have been expelled. The true Buddhists all put something into the bowl, rice generally and curry, sometimes fish. When they were full we went back to the monastery, and all the priests, old ones and novices, had dinner from what we'd brought them. Then we gave the rest to the beggars, for blessed a thing can we eat from noon to the next sunrise."

" 'Twas hard, the first months, eating nothing but curry and rice. Now, bless you, I'd not eat European food if it was set down before me. Every blessed afternoon I studied the history of Buddha and Burmese with the old priests. 'Twas a fine thing for me. Before I found the true faith I was that blessed ignorant I could hardly read my own tongue. Today, bless you, I know eight languages and ins and outs of every religion on the footstool. I was a vile curser when I was hoboing in the States, and 'twas hard to quit it. But every time I started to say a cuss-word I thought of the revered Gautama and said blessed' instead, and I'm master of my own tongue now."

" Then you really worship the Buddhist god," put in J ames.

" There again," cried the Irishman, "is the ignorance of those who follow that champion faker J esus, the son of Mary and a drunken Roman soldier. The Buddhists worship no-one. We revere Buddha, the finest man that ever lived, because he showed us the way to attain Nirvana, which is to say heaven. He was no god, but a man like the rest of us."

"After five years I was ordained and five more I was teaching the other novices and the children, the Tavoy monastery being the big school of Rangoon. Then I was made an elder, then the abbot of the monastery, then after fifteen year, the Bishop, as you would call it, of Rangoon. The abbots and the bishops have no need to teach, but, bless you, I'm teaching yet, it being my duty to give to others of the true faith what I've learned."

" 'Tis the bishop's place to travel, and in these six years gone I've visited every blessed Buddhist kingdom in Asia, from J apan to Ceylon; and I was in Lhasa talking with the Dalai Lama long before Younghusband would have dared to show his face there. There's never a Buddhist king nor prince that hasn't treated me like one of them, though they'd have cut the throats of any other European. I'm coming back now from three months with the prince of Nepal, teaching his priests, him giving me the ticket to Chittagong."

"But if you can't touch money? - " I began.

"In heathen lands we can carry enough to buy our curry and rice. I have here three rupees," - drawing out a knotted handkerchief from the folds of his robe - "if there's an anna of it left when I land in Burma I'll give it to the first beggar to ask me. In Buddhist countries the blessed people give us what we need, as they'll give it to anyone else that's needing it.

They're not superstitious, selfish beasts like these dirty Hindus. When we come to Chittagong you can stop with me. Then I'll give you a chit to the Tavoy in Rangoon and you can stay there as long as ever you like. If ever you have no place to put up in a Buddhist 
town, go to the monastery. And if you tell them you know me, see how fine you'll be treated.

"Aye, but we 'd have to know your name," I suggested.

"As I was going to tell you, it 's U (OO) Damalaku."

"Don't sound Irish," I remarked.

"No, indeed," laughed the priest, "that's my Buddhist name. The old one was Larry O'Rourke."

"You call that graft, you and your likes," he concluded, turning to Rice, "giving up your name and your hair and a fine moustache, and your clothes, and owning never an anna, and having your own ignorant race laughing at you, and having your body burned by the priests when you're born again in another one! But it's the true philosophy, bless you, and the right way to live. Why is it the white men that come out here die in ten years? Do you think it' the climate? Bless you, no, indeed, it's the strong drink and the women. Look at me. Would you think I was fifty-five if I hadn't told you?"

He was, certainly, the picture of health ; deeply tanned, but with the clear eye and youthful poise of a man twenty years younger. Only one hardship, apparently, had he suffered during two decades of the yellow robe. His feet were broad and stumpy to the point of deformity, heavily calloused, and deeply scarred from years of travel over many a rough and stony highway.

"It's a strange story," said J ames.

"I'm asking no-one to take my word in this world of liars," responded the Irishman, somewhat testily. " Here you have the proof."

He thrust a hand inside his robe and, drawing out a small, fat book, laid it in my lap. It contained more than a hundred newspaper clippings, bearing witness to the truth of nearly every assertion he had made. The general trend of all may be gleaned from one article, dated four years earlier. In it the reader was invited to compare the receptions tendered Lord Curzon and the Irish Buddhist in Mandalay. The viceroy, in spite of months of preparation for his visit, had been received coldly by all but the government officials. Damalaku had been welcomed by the entire population, and had walked from the landing stage to the monastery, nearly a half-mile distant, on a roadway carpeted with the hair of the female inhabitants, who knelt in two rows, foreheads to the ground, on either side of the route, with their tresses spread out over it.

When he had despatched a Gargantuan bowl of curry and rice in anticipation of eighteen hours of fasting, the Irishman drew us around him once more and began a long dissertation on the philosophy of Buddha. Two morning trains had poured a multi-colored rabble into the mud village, and the deck of the steamer was crowded with natives huddled together in close-packed groups, each protected from pollution by a breastwork of bedraggled bundles. Newcomers picked their way gingerly through the network of alleyways between the isolated tribes, holding their garments - when such they wore close round them, and joined the particular assembly to which their caste assigned them. 
The Irishman, at first the butt of Hindu stares, was soon surrounded by an excited throng of Burmese travelers.

As the afternoon wore on a diminutive Hindu, of meek and child-like countenance, appeared on board, and, hobbling in and out through the alleyways on a clumsily-fitted wooden leg, fell to distributing the pamphlets that he carried under one arm. His dress stamped him as a native Christian missionary. Suddenly, his eye fell on Damalaku, and he stumped forward open-mouthed.

"What are you, sahib? " he murmured in a wondering tone of voice.

"As you see," replied the Irishman, " I am a Buddhist priest."

"Bu - but what country do you come from ?"

"I am from Ireland."

Over the face of the native spread an expression of suffering, as if the awful suspicion that the missionaries to whom he owed his conversion had deceived him, were clutching at his heartstrings.

"Ireland?" he cried, tremulously, "Then you are not a Buddhist! Irishmen are Christians. All sahibs are Christians," and he glanced nervously at the grinning Burmese about us.

"Yah! That's what the Christian fakers tell you," snapped the Irishman. "What's that you've got?"

The Hindu turned over several of the tracts. They were separate books of the Bible, printed in English and Hindustanee.

"Bah!" said Damalaku, "It's bad enough to see white Christians. But the man who swallows all the rot the sahib missionaries dish up for him, when the true faith lies not a day's distance, is disgusting. You should be ashamed of yourself."

"It's a nice religion," murmured the convert.

"Prove it," snapped the Irishman.

The Hindu accepted the challenge, and for the ensuing half-hour we were witnesses of the novel spectacle of a sahib stoutly defending the faith of the East against a native champion of the religion of the West. Unfortunately, he of the wooden leg was no match for the learned bishop. He began with a parrot-like repetition of Christian catechisms and, having spoken his piece, stood helpless before his adversary. A school boy would have presented the case more convincingly. The Irishman, who knew the Bible by heart, evidently, from Genesis to Revelations, quoted liberally from the Scriptures in support of his arguments, and, when the Hindu questioned a passage, caught up one of the pamphlets and turned without the slightest hesitation to the page on which it was set forth.

Entangled in a network of texts and his own ignorance, the native soon became the laughing-stock of the assembled Burmese. He attempted to withdraw from the controversy by asserting that he spoke no English. Damalaku addressed him in Hindustanee. He pretended even to have forgotten his mother tongue, and snatched childishly at the pamphlets in the hands of the priest. When all other means failed, he fell back on the final subterfuge of the Hindu - and began to weep. Amid roars of laughter he clutched the 54 
tracts that the Irishman held out to him and, with tears coursing down his cheeks, hobbled away, looking neither to the right nor left until he had disappeared in the mud village.

The steamer put off an hour later and, winding in and out among the tortuous channels of the delta, landed us at sundown in Chandpore, a replica of Goalando. Our passage - for the captain had refused to "slip" us - had reduced our combined fortunes to less than one fare to Chittagong. We scrambled with the native throng up the slimy bank to the station, resolved to attempt the journey without tickets. It lacked an hour of train time.

"Will you take this to Chittagong?" I asked, thrusting the carpet-bag into the hands of the Irish bishop. "We're going to beat it."

"Sure," replied the priest, " it should be easy by night with this crowd." 129

I have quoted this piece in extenso to give a sense of how the everyday incidents of a life somewhere between hobo and bhikkhu, the repartee of friendly banter and public controversy, and the exhibition of one's own life choices combined into a single "performance" with a character all its own. In this performance, Buddhist Revival concern with how monks should behave (rather than colonial rules on how whites should act in front of "natives"), a self-confident pride in one's survival through hard times (rather than a gentlemanly concern with respectability), a cultural nationalist defence of Asian religion and a plebeian critique of Asian myth go hand-in-hand in ways that were more effective at the time than we might suppose.

It is easy to see why such a man might have been popular, and found it easy to gain supporters, allies and patrons, to build organisations and leave missionaries spluttering. If despite our best efforts we cannot as yet pin down the details of his earlier life or identify when and how he learned these organising skills, this is no doubt at least in part because he did not wish his contemporaries to. As Thompson noted, "if it was difficult to identify a Muggletonian two hundred years ago, we will find it more difficult to identify him today" ${ }^{130}$. Similarly, if the best efforts of journalists, missionaries and the British courts could not get beyond generalities in identifying Dhammaloka's previous persona - or in finding out what became of him previously - we will find it hard to do better.

However, what we can say is that much of his persona required no explanation - whether in his own mind, that of his supporters or indeed those of his enemies. Nobody seems to have found it surprising that Buddhism, in imperial Asia, should be defended against Christian missionaries in the language of western free thought. Nor was it particularly surprising (except to the Indian convert) that this should be done by a beachcomber bhikkhu; and it was certainly no surprise to find a working-class Irishman politically troublesome.

The only real surprise was in the level of organisation, intellectual resources, supporters and publicity that Dhammaloka could mobilise for his concerns. Then as now, he did not

\footnotetext{
129 Franck, Vagabond J ourney, 361 - 6.

130 Witness against the Beast, 69.
} 
fit the image of a national, let alone an international, religious actor. As this article's "search for Dhammaloka" has hopefully shown, however, his organising skills and intellectual repertoire were widely shared among plebeians, radicals and freethinkers at the start of the twentieth century. This repertoire played a significant role in the early development of western Buddhism - and Buddhist Modernism in Asia. 


\section{Bibliography}

Newspapers and Popular J ournals

Arakan Times (Akyab)

Bangkok Times and Weekly Mail

Bible Study Union Lessons (Boston)

Blue-Grass Blade (Lexington, KY)

Buddhist Review (London)

Burma Echo (Rangoon)

Das freie Wort (Frankfurt)

Deseret Evening News (Salt Lake City)

Eastern Buddhist (Kyoto)

Humanitarian Review (Los Angeles)

Lucifer / Theosophical Review (London)

Maha-Bodhi and the United Buddhist World (Calcutta)

Missions: An International Baptist Magazine (Bristol, CT)

Straits Times (Singapore)

Sunday Independent (Dublin)

The Independent (Boston)

The Truth Seeker (New York)

Theosophy (New York)

Times of Burma (Rangoon)

Wesleyan-Methodist Magazine (London)

General references

Avrich, Paul. The Modern School Movement: Anarchism and Education in the United States. Oakland, CA: AK Press, 2006.

Barnard, Toby. "Reading in Eighteenth-century Ireland: Public and Private Pleasures," in The Experience of Reading: Irish Historical Perspectives, edited by Bernadette 
Cunningham and Máire Kennedy 60-77. Dublin: Rare Books Group of the Library Association of Ireland / Economic and Social History Society of Ireland,1999.

Barrow, Logie. Independent Spirits: Spiritualism and English Plebeians 1850- 1910. London: Routledge and Kegan Paul, 1986.

[Brown, George W?] The Teachings of J esus not Adapted to Modern Civilization. Rangoon: Buddhist Tract Society, 1910.

Clark, Francis. "Buddhism on the Warpath." The Independent: A Weekly J ournal of Free Opinion, Devoted to the Consideration of Politics, Social and Economic Tendencies, History, Literature and the Arts 6868, no. 3192 (Feb 1910): 246-9.

. Memories of Many Men in Many Lands. $2^{\text {nd }}$ ed. Boston: United Society of Christian Endeavour, 1922.

Connolly, J ames. Labour, Nationality and Religion. Dublin: New Books / Irish Socialist Library, 1972 [1910].

Cotes, Mrs. Everard. "The Ordination of Asoka." Harper's Monthly Magazine 105 (1902): 753-60.

Coulter, Carol. The Hidden Tradition: Feminism, Women and Nationalism in Ireland. Cork: Cork University Press, 1993.

Cox, Laurence. "Lawrence O'Rourke / U Dhammaloka: Working-class Irish Freethinker, and the First European Bhikkhu?" J ournal of Global Buddhism 10 (2009): 135 - 144.

Cox, Laurence and Griffin, Maria. "Border Country Dharma: Buddhism, Ireland and Peripherality." J ournal of Global Buddhism 10 (2009): 93 - 125.

. "The Wild Irish Girl and the 'Dalai Lama of Little Thibet': The Long Encounter Between Ireland and Asian Buddhism." In New religion in Ireland: Alternative Spiritualities, Migrant Religions, the New Age and New Religious Movements, ed. Olivia Cosgrove, Laurence Cox, Carmen Kuhling and Peter Mulholland. Cambridge: Cambridge Scholars Publishing, forthcoming 2011.

Cox, Laurence. "Plebeian freethought and the politics of anti-colonial solidarity: Irish Buddhists in imperial Asia." Paper at the 15th international Alternative Futures and Popular Protest conference, Manchester Metropolitan University, 2010.

Crow, J ohn L. "The White Knight in the Yellow Robe: Allan Bennett's Search for Truth." Master's thesis, University of Amsterdam, 2009.

Davies, Megan and Keith Flett. "The tenacity of activism?" Paper at the $14^{\text {th }}$ international Alternative Futures and Popular Protest conference, Manchester Metropolitan University, 2009.

de Camp, Lyon Sprague. Lost Continents: the Atlantis Theme in History, Science and Literature. New York: Dover, 1970.

Denis, Leo and White, Arthur. Water-Powers of Canada. Ottawa: Mortimer Co., 1911. Dhammaloka. "From Far-Off India." Blue Grass Blade 23, no. 3 (1909): 6-7. 
. "A Hindu on Paine." Blue Grass Blade 23, no. 3 (1909): 7.

Donogh, Walter. The History and Law of Sedition and Cognate Offences in British India..., 2nd ed. Calcutta: Walter Spink, 1914.

Dukes, Edwin. Everyday Life in China: Or, Scenes Along River and Road in Fuh-kien. London: Religious Tract Society, 1885.

Egoroff, Sophia. Buddhism: The Highest Religion. Rangoon: Burma Echo Press / Buddhist Tract Society, 1909.

Fisher, Gertrude. A woman alone in the heart of J apan. Boson: LC Page \& Co., 1906.

Foley, Tadhg and Maureen O'Connor, eds., Ireland and India: Colonies, Culture and Empire. Dublin: Irish Academic Press, 2006.

Franck, Harry. A Vagabond J ourney Around the World: A Narrative of Personal Experience. New York: Century, 1910.

Hapgood, Hutchins. The Spirit of Labor. Urbana, IL: University of Illinois Press, 2004 [1907].

Harris, Elizabeth. Ananda Metteyya: The First British Emissary of Buddhism. Kandy: Buddhist Publication Society, 1998.

Higbie, Frank. Indispensable Outcasts: Hobo Workers and Community in the American Midwest, 1880 - 1930. Urbana, IL: University of Illinois Press, 2003.

Hill, Christopher. The World Turned Upside Down: Radical Ideas during the English Revolution. Harmondsworth: Penguin, 1975.

Ingalls, Sheffield. History of Atchison County, Kansas. Tucson, AZ: Americana Unlimited, 1974 [1916].

Kennerley, Alston. "Writing the History of Merchant Seafarer Education, Training and Welfare: Retrospect and Prospect." The Northern Mariner / Le Marin du Nord XII no. 2 (April 2002): 1 - 21.

Linebaugh, Peter and Rediker, Marcus. The Many-Headed Hydra: The Hidden History of the Revolutionary Atlantic. Boston: Beacon Press, 2001.

Macdonald, George. Fifty Years of Freethought: Being the Story of the Truth Seeker, with the Natural History of its Third Editor. New York: Truth Seeker, 1931.

MacManus, Antonia. The Irish Hedge School and its Books, 1695 - 1831. Dublin: Four Courts, 2002.

McLoughlin, Barry. Left to the Wolves: Irish Victims of Stalinist Terror. Dublin: Irish Academic Press, 2007.

McMahan, David. The Making of Buddhist Modernism. Oxford: Oxford University Press, 2008.

Morris, Henry. Life of J ohn Murdoch LLD: The Literary Evangelist of India. London: Christian Literature Society for India, 1906. 
Murray, Paul. A Fantastic J ourney: The Life and Literature of Lafcadio Hearn. Folkestone: J apan Library / Curzon, 1993.

Nevin, Donal. James Connolly: "A Full Life." Dublin: Gill and Macmillan, 2005.

Noyes, Rufus King. Views of Religion. Boston: LK Washburn, 1906.

Peebles, James. What is Buddhism? Colombo: Sri-Dharma-Sri publishers, 1907-8.

Purser, William Charles Bertrand. Christian Missions in Burma. London: Society for the Propagation of the Gospel in Foreign Parts, 1911.

. Modern Buddhism in Burma: being an epitome of information received from

missionaries, officials and others. Rangoon: Christian Literature Society, 1914.

Pye, Dennis. Fellowship is Life: The National Clarion Cycling Club, 1895 - 1995. Bolton: Clarion, 1995.

Remsburg, J ohn E. Thomas Paine, The Apostle of Liberty; An Address Delivered in Chicago, J anuary 29, 1916. Including the Testimony of Five Hundred Witnesses. New York,: The Truth Seeker Co., 1917.

Richard, Timothy. Forty-five Years in China: Reminiscences. London: Fisher Unwin, 1916.

Rothstein, Andrew. A House on Clerkenwell Green. $2^{\text {nd }}$ ed. London: Marx Memorial Library, 1983.

Royle, Edward. Victorian Infidels: The Origins of the British Secularist Movement 1791 1866. Manchester: Manchester University Press, 1974.

Shipley, Stan. Club Life and Socialism in Mid-Victorian London. Oxford: History Workshop, 1972.

Snowden, J ames. The Truth about Christian Science: The Founder and the Faith Philadelphia: Westminster Press, 1920.

Tarrow, Sidney. Power in Movement: Social Movements and Contentious Politics, $2^{\text {nd }}$ ed. Cambridge: Cambridge University Press, 1998.

Taylor, J ohn. From Self-Help to Glamour: The Working Man's Club, 1860 - 1972. Oxford: History Workshop, 1972.

Thompson, E. P. The Making of the English Working Class. London: Gollancz, 1963. . Witness Against the Beast: William Blake and the Moral Law. Cambridge: Cambridge University Press, 1963.

Turner, Alicia. "Buddhism, Colonialism and the Boundaries of Religion: Theravada Buddhism in Burma 1885-1920." PhD diss., The University of Chicago, 2009.

Weber, Max. Soziologische Grundbegriffe. Stuttgart: UTB, 1984.

Young, Richard Fox, and Jī Pī Vī Sōmaratna. Vain Debates: The Buddhist-Christian Controversies of Nineteenth-century Ceylon. Vienna: Institute of Indology, University of Vienna, 1996. 